\title{
Testing cost-effective methodologies for flood and seismic vulnerability assessment in communities of developing countries (Dajç, northern Albania)
}

\author{
Veronica Pazzi, Stefano Morelli, Francesco Fidolini, Elvis Krymi, Nicola \\ Casagli \& Riccardo Fanti
}

To cite this article: Veronica Pazzi, Stefano Morelli, Francesco Fidolini, Elvis Krymi, Nicola Casagli \& Riccardo Fanti (2016) Testing cost-effective methodologies for flood and seismic vulnerability assessment in communities of developing countries (Dajç, northern Albania), Geomatics, Natural Hazards and Risk, 7:3, 971-999, DOI: 10.1080/19475705.2015.1004374

To link to this article: http://dx.doi.org/10.1080/19475705.2015.1004374 \section{(c) 2015 The Author(s). Published by Taylor \&
Francis.}

Submit your article to this journal $\pi$

View related articles $₫$
曲 Published online: 03 Feb 2015.

$$
\text { 凹II Article views: } 777
$$




\title{
Testing cost-effective methodologies for flood and seismic vulnerability assessment in communities of developing countries (Dajȩ, northern Albania)
}

\author{
VERONICA PAZZI $\dagger *$, STEFANO MORELLI $\dagger$, FRANCESCO FIDOLINI $\dagger$, \\ ELVIS KRYMI $\ddagger$, NICOLA CASAGLI $\dagger$ and RICCARDO FANTI $\dagger$ \\ $\dagger$ Department of Earth Sciences, University of Firenze, Firenze 50121, Italy \\ $\ddagger$ Department of Geography, University of Shkoder "Luigj Gurakuqi", \\ Shkoder 4001, Albania
}

(Received 24 March 2014; accepted 2 January 2015)

\begin{abstract}
Nowadays many developing countries need effective measures to reduce the disaster related risks. Structural interventions are the most effective to achieve these aims. Nevertheless, in the absence of adequate financial resources different low-cost strategies can be used to minimize losses. The purpose of this paper is to demonstrate that the disaster risk reduction can be gathered building a community coping capacity. In the case study, flood and seismic analyses have been carried out using relatively simple and low-cost technologies, fundamental for governments and research institutions of poorly developed countries. In fact, through the acquisition and dissemination of these basic information, a reduction of vulnerability and risk can be achieved. In detail, two methodologies for the evaluation of hydraulic and seismic vulnerability were tested in the Dajç municipality (Northern Albania), a high-seismicity region that is also severely affected by floods. Updated bathymetric, topographic and hydraulic data were processed with HEC-RAS software to identify sites potentially affected by dykes overflowing. Besides, the soil-structure interaction effects for three strategic buildings were studied using microtremors and the Horizontal to Vertical Spectral Ratio method. This flood and seismic vulnerability analysis was then evaluated in terms of costs and ease of accessibility in order to suggest the best use both of the employed devices and the obtained information for designing good civil protection plans and to inform the population about the right behaviour in case of threat.
\end{abstract}

\section{Introduction}

Geohazards are naturally occurring geological, hydrological or geomorphological phenomena that can potentially cause damage or uncontrolled risk increase to the human beings, their properties or the environment (Doornkamp 1989). Among all the natural occurrences, volcanic eruptions, landslides, floods and earthquakes may be regarded as the most relevant damaging processes (Alcántara-Ayala 2002). Their hazard begins whenever small changes in the initial conditions of the Earth surface induce sudden modifications in long-term behaviour (Scheidegger 1994). Moreover, according to McCall (1992) and Lekkas (2000) and many other authors, geohazards

*Corresponding author. Email: veronica.pazzi@unifi.it 
involve also the interaction of human activities and any natural process of the planet that originates in the solid earth, oceans and atmosphere. Nevertheless, considering this definition, the experience gained until today in this field has shown that the division and differentiation of the two mentioned contributions is very difficult, especially in the circumstance where a catastrophic event is very much influenced and made worse by the anthropic intervention (Zulherman et al. 2006). Extreme natural phenomena causing natural hazards are not deemed as controllable events (Hodgkinson \& Stewart 1991) and sometimes they are perceived to be inevitable, but however their catastrophic impact is not totally unavoidable and it can be significantly reduced using different methods of mitigation. Nowadays, in many developing countries, characterized by heavy concentration of people in restricted areas, poorly regulated urbanization and uncontrolled land use, a natural hazard can result in severe effects, even if its original impact was not so critical. The realization of risk maps is an essential tool for planning effective measures of risk mitigation (from the implementation of the structural countermeasures up to the improvement of the resilient capacity of the exposed population) and nowadays several low-cost technologies are available for such a scope (Tobin \& Montz 2004; Paul 2011).

Albania, which belongs to the above-mentioned category of countries, is vulnerable to a range of natural events with a catastrophic nature. The exposure of Albanian population to these occurrences is mainly due to poverty, poor infrastructure and communications, a rapid urban growth and a range of environmental factors caused by the human negligence (United Nations Development Programme 2003). The greatest disaster threats in Albania come from severe earthquakes and riverine floods both at large and small scale (Allaraj et al. 2012).

As concerns floods, they generally have a pluvial origin and occur during November-March, when $80 \%-85 \%$ of the annual precipitations are concentrated (Bogdani 2006; Pojani \& Tola 2010). The main Albanian rivers flow from the mountainous eastern regions to the western coastal plains (Adriatic lowlands), where more than $50 \%$ of the whole population lives and the demographic growth is continuous and conspicuous (World Bank 2003). During the major flood events the Adriatic lowlands, especially close to the main river mouths, can be largely inundated for several weeks (Bogdani 2006). Among them the plains of the Drin River in the north and the Vijosë river in the south are especially flood-prone (World Bank 2003).

On the other hand, Albania is usually affected by intense earthquake activity (Becchi et al. 2011). The strongest and most destructive recorded events in the last century were: (i) the Shkoder earthquake on June 1, 1905 (Ms = 6.6); (ii) the lake Ohrid earthquake on February 18, 1911 (Ms = 6.7); (iii) the Tepelene earthquake on November 26, 1920 (Ms = 6.4); (iv) the Durres earthquake on December 17, 1926 (Ms = 6.2); and (v) the Montenegro earthquake on April 15, 1979 (Ms = 6.9). In order to prevent new catastrophic consequences the authorities have begun to take an interest in the problem insomuch as a detailed seismic zoning of Albania has started in 1995 and it is still underway (United Nations Development Programme 2003).

So, as shown, the geohazards assessment is a crucial point for Albania, which has undergone a rapid development after the political changes of the 1990s and it still is undergoing the abandonment of a centralized land management in favour of a more democratic administration, with critical results for the protection of most of the rural areas (Deininger et al. 2012). Moreover many people are coming back to their own country after many years of mass emigration, ruining the national territory with the 
construction of new houses and facilities without appropriate methods, materials and regulation (Muço et al. 2012). In such social context the exploitation of riverbeds for the illegally dredging of construction materials disturbs the natural equilibrium of the watercourses (Pojani \& Tola 2010). This results in widespread land degradation and in a chaotic urban development, which represent a major problem for the national civil protection. In recent times also the migration from rural areas towards the big conurbations is prevalent and, since the new suburban areas are usually located in high-risk parcels, with significant vulnerability to natural hazards, their rate of sprawl represents a significant further problem (Gaetani et al. 2008). However the national civil protection system, in terms of subsidiary institutional and volunteer components, is relatively young in Albania. The progressive decentralization of the competences triggered by all the political changes is going on together with the acquisition of new information and protocols for the local emergency management and the risk reduction.

As it happens in many communities, risk reduction and vulnerability often are not the main worries until the disaster occurs. Residents have other issues that assume priority, and local administrations do not want to dwell on the hazard vulnerability of their communities as it might hurt economic investment and growth (Cutter et al. 2008). Nevertheless, the economic losses due to natural disasters are always greater than the investments needed to reduce their impact. In particular many advantages can be obtained investing in the preparedness and the consciousness of the community about the risks insisting on that area.

However, several approaches to vulnerability and risk assessment have been developed in literature, both in theoretic frameworks and in different scale case studies. In the field of natural hazards, the UNISDR (2009) definitions can be considered the keystone, even if the exact meaning of "vulnerability" continues to represent a debated issue, in special when different research fields are involved. An interesting review on the vulnerability components definition has been recently proposed by Costa and Kropp (2013) that highlighted the links between some methodologies and case studies in the field of natural/man-made disasters and climate change analyses. In the risk-hazard context, the approaches extended from qualitative to strictly quantitative methods, with tangible differences between social and environmental contexts (Thywissen 2006; Ionescu et al. 2009; Fuchs et al. 2011; Hinkel 2011). In this framework, referring to the definitions in Birkmann (2006), the main purpose of this paper is to demonstrate that reduced-cost technologies and methods, whose easy accessibility is fundamental for government and academic institutions of underdeveloped countries, can be effectively used to build community coping capacity, intended as the way in which people or organizations use available resources and abilities to face adverse consequences of a disaster (UNISDR 2009). An interesting reference in this sense is represented by the experience of UNISDR and UN-Habitat in the definition of tools for the assessment of school and hospital safety for multi-hazards in developing countries (UNISDR 2010). In the case study, considering the two more recurrent natural threats in Albania, a municipality in the district of Shkoder (northern Albania) was chosen to develop two different approaches for the rapid assessment of local vulnerability to floods and seismicity. The approach is then evaluated in terms of technologies' cost-effectiveness and ease of accessibility in order to suggest to those organizations dealing with disasters (including local authorities and volunteers) the best use both of the employed devices and the obtained information for designing good civil protection plans, as well as to correctly manage the considered 
natural emergencies and to inform the population about the right behaviour in case of threat.

\section{Study area}

\subsection{Geomorphological context}

The study area is the municipality of Dajç, located in the Shkoder district (northern Albania), which is one of the most important hydrographic hubs of the whole country. The Dajç village rests on a wide alluvial plain, $12 \mathrm{~km}$ south-west of Shkoder, along the left bank of the Buna River, the only emissary of the Shkoder lake (figure 1). This lake is supplied by a $5,200 \mathrm{~km}^{2}$ drainage basin $(20 \%$ in Albania, $80 \%$ in Montenegro; Pano \& Avdyli 1984). The Buna River, flowing with a sinuous trend from the south-eastern reach of the lake in a NE-SW direction, comes to the Adriatic Sea in correspondence of the city of Velipojë. About $2 \mathrm{~km}$ south-west of Shkoder, the Buna River receives the water of the Drin River, which flows from the mountainous regions in the eastern part of the country. This river encompasses a drainage basin of about $14,200 \mathrm{~km}^{2}$ including Albania, Macedonia and Kosovo (figure 1). As a consequence, the drainage basin of the Buna-Drin river system extends for about $20,000 \mathrm{~km}^{2}$, almost half of the total hydrographic surface of Albania.

The Buna River alluvial plain is generally wide, but locally interrupted by NW-SE oriented and up to $1,600 \mathrm{~m}$ high ridges (figure $1(b)$ ) that represent anticlinal folds involving the rocky substrate. The river has a meandering trend and it is characterized by one single channel for most of its course. The alluvial plain is poorly drained and during the wet season (November-January) it is typically waterlogged. Terrains are widely used for agricultural aims and houses are concentrated in small villages dispersed along the riverbeds or not far from them (figure 2).
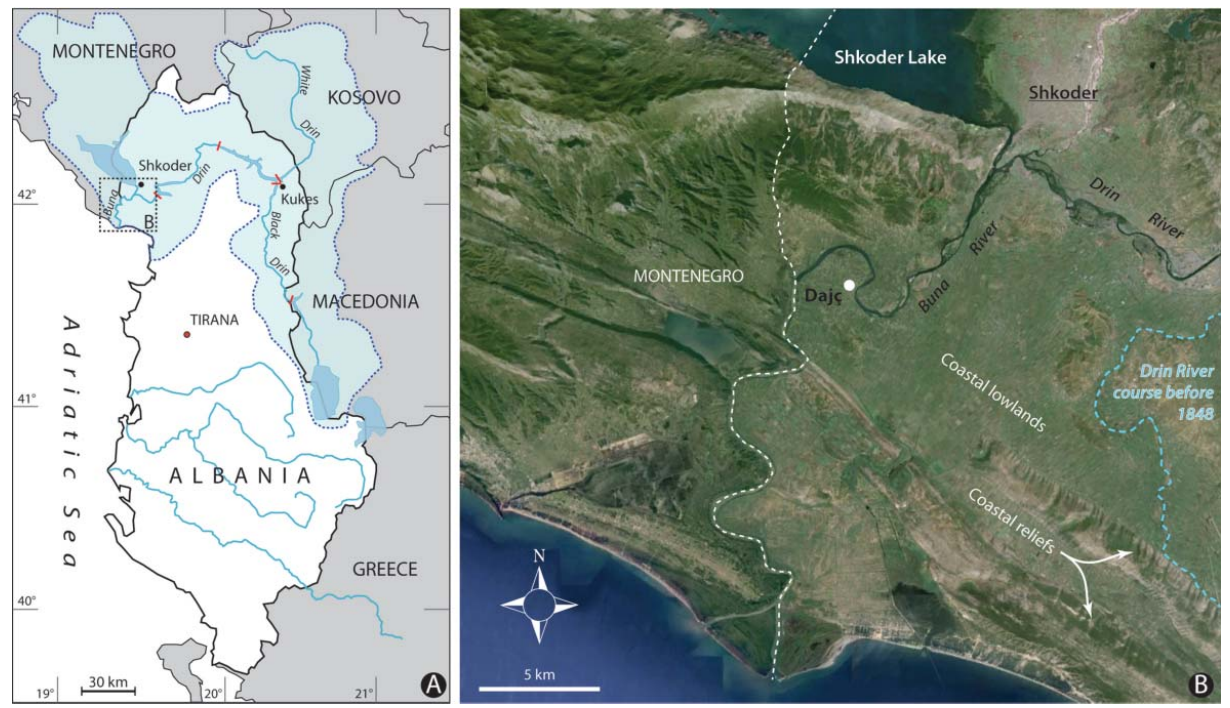

Figure 1. Location map of the study area. (a) Areal extension of the Buna-Drin drainage basin (in light blue) and position of the dams (in red) interrupting the Drin River course. (b) Detailed view of the study area. To view this figure in colour, please see the online version of the journal. 

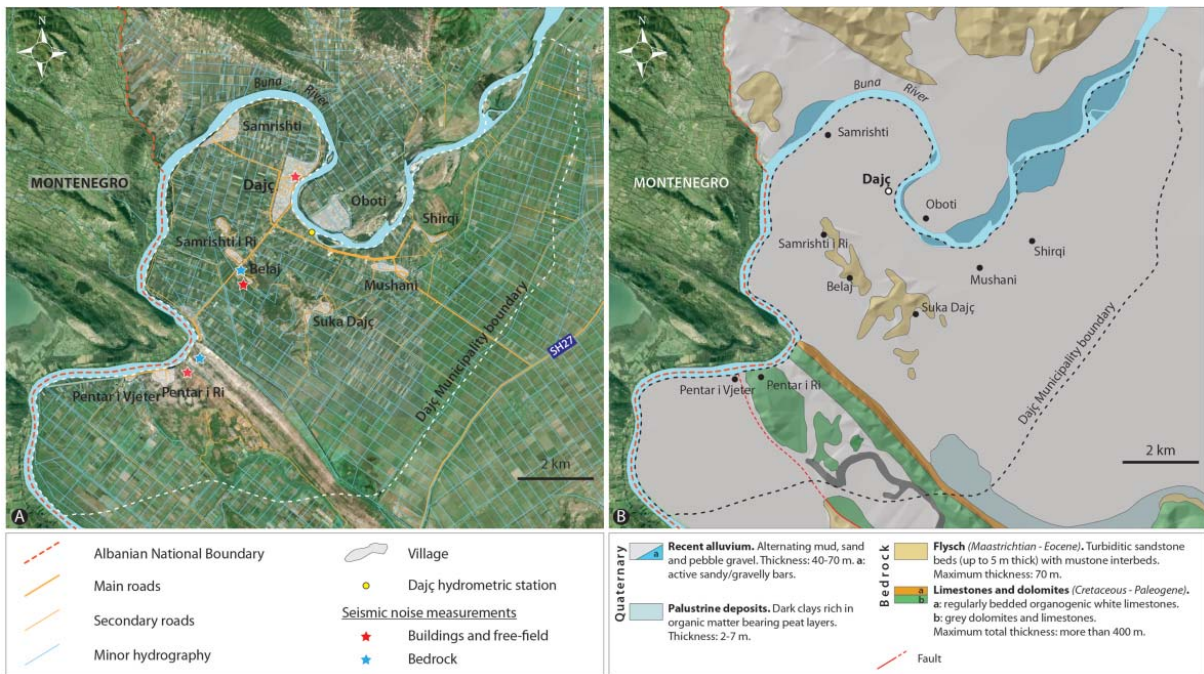

Figure 2. The Dajç municipality. (a) Location of the main villages and infrastructure. (b) Geological sketch map (modified after Zaçaj et al. 2010).

\subsection{Climate and hydrology}

Northern Albania presents the typical Mediterranean climate (Qiriazi \& Sala 2000), with high precipitation during autumn and winter, sparse during spring and rare in summer (figure 3). The areal distribution of precipitations is quite complex due to microclimatic factors related to local reliefs (Grazhdani \& Shumka 2007). Thus the Albanian Alps region represents the area with the mean annual rainfall maximum

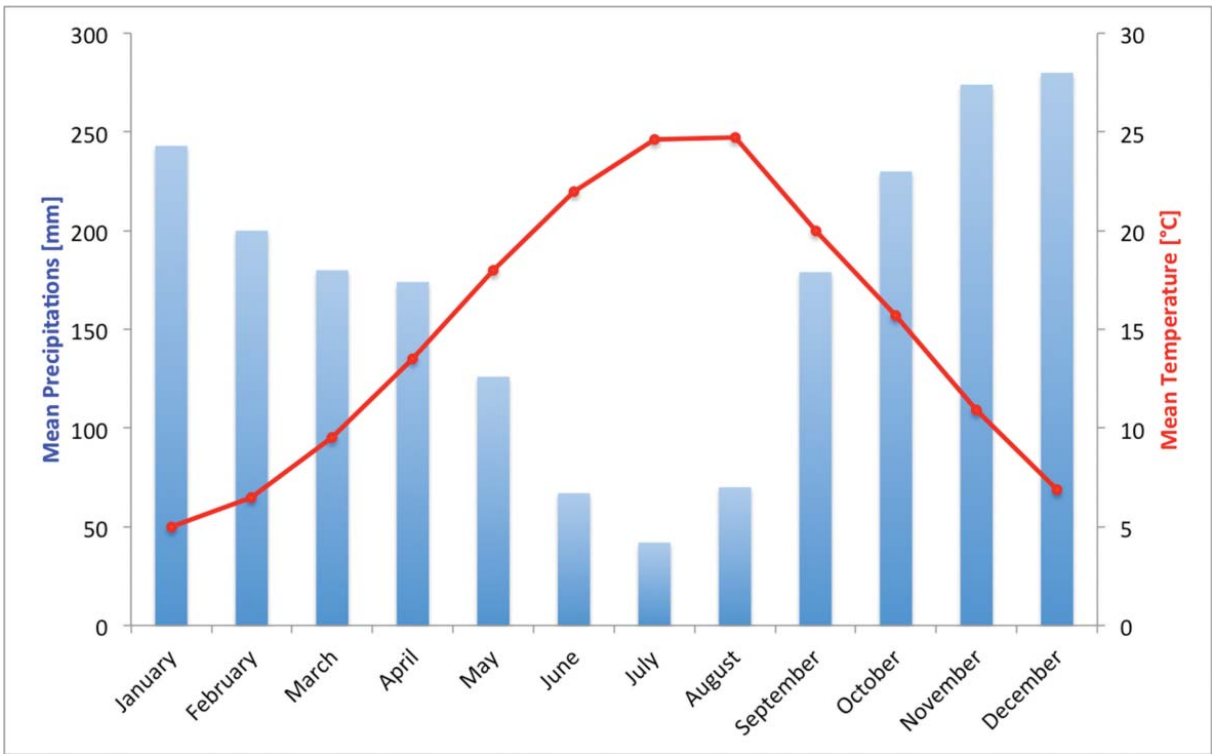

Figure 3. Chart showing the mean monthly values for rainfall and temperature in the Shkoder area. 
$(3,000-3,500 \mathrm{~mm} /$ year $)$, while along the coast values are significantly lower $(<2,000$ $\mathrm{mm} /$ year). The Albanian Alps region is the area characterized by the highest values regarding also the daily maximum rainfall, reaching relevant values in the Shkoder surroundings too (Çetinkaya \& Kaymaz 2013).

A dry and hot summer, with high evapotranspiration, and a cold and wet winter, mainly due to cold humid winds coming from the Adriatic Sea, characterize the Shkoder district climate. The reliefs parallel to the coast, locally reaching $1,600 \mathrm{~m}$ in height, represent a steep barrier for the westerly winds, causing a rapid uplift of humid air masses coming from the sea and producing abundant rainfalls on the alluvial plains behind. As a result the Shkoder district records a mean annual rainfall of about 1,900 mm/year, with local peaks of 3,000 mm/year in some sectors of the basin. The mean temperature in January, the coldest month, is about $5{ }^{\circ} \mathrm{C}$, while in July and August the values reach about $25^{\circ} \mathrm{C}$ (Cetinkaya \& Kaymaz 2013; figure 3).

Precipitations have clearly a direct impact on the hydrologic balance of the Shkoder lake and, thus, on the Buna River discharge. According to the change in precipitation/evapotranspiration rate during the year, the lake level oscillates about $5 \mathrm{~m}$. Just downstream of the lake, the Buna River has a mean annual flow of about $320 \mathrm{~m}^{3} / \mathrm{s}$ (Pano \& Avdyli 1984). Nevertheless, downstream of the confluence with the Drin River, the flow increases dramatically due to the big amount of water supplied by the latter's drainage basin. The Drin River comes from the union of two main streams: the White and Black Drin, flowing in the eastern part of the country. These two rivers, flowing respectively with a $\mathrm{N}-\mathrm{S}$ and a $\mathrm{S}-\mathrm{N}$ trend, converge near the city of Kukes and there the Drin River starts flowing to the west. The river flow is interrupted by five dams (red lines in figure 1(a)) built to produce electric energy. Two of them are located upstream of Kukes while the other three are placed downstream of the confluence. Such dams significantly altered the hydrological equilibrium of the Drin River, whose bedload is mostly trapped by the engineering barriers, resulting in intense erosional phenomena downstream of the dams (Pojani \& Tola 2010). Furthermore the Buna and Drin rivers have not always been confluent. The Drin River has a minor branch, presently inactive, bifurcating from the major trunk just downstream the lowermost dam. This branch has been the main river course until 1846-1848, when repeated and dramatic floods promoted the partial abandonment of this reach and the birth of the confluence with the Buna River (figure 1(b)). It is clear that presently the Buna River, which formerly had a relevantly smaller drainage basin, downstream of the confluence with the Drin has an undersized riverbed with respect to the discharge it hosts. As a consequence the hydraulic capacity of the Buna River results insufficient to drain the huge amounts of water supplied by the Drin River, especially in case of dams' opening.

\subsection{Geological setting}

From a geological point of view the Shkoder area is undoubtedly one of the most complex of the whole country. This area is crossed by the Shkoder-Peja fault, which separates the Dinarides to the north from the Hellenides, to the south. These two chains, representing the southernmost branch of the Alpine orogeny, consist of continental thrust sheets and previously obducted ophiolites piled up during Late Cretaceous to Cenozoic time (Schmidt et al. 2008). The Shkoder-Peja structural lineament is an active seismogenic transverse fault responsible for many of the 
earthquakes that affected the area in the recent past. In the surroundings of Shkoder this fault juxtaposes the calcareous rocks of the Albanian Alps to the north with terrigenous ones to the south. In the study area the latter consist of alternating sandstones and mudstones of turbiditic origin and Maastrichtian-Eocene age. These sedimentary rocks are involved in SW verging folds parallel to the main chain and represent the rocky substrate, only locally exposed, of the Buna River alluvial plain sediments between Shkoder and the westernmost carbonatic reliefs. Within the study area these rocks crop out close to the villages of Belaj, Samrish and Suka-Dajç (figure 2), where they form an anticline. These deposits rest conformably on a thick calcareous-dolomitic Cretaceous succession, widely exposed in the reliefs close to the coast and in the surroundings of the Pentar village.

The Buna River Quaternary alluvial sediments unconformably cover the Cretaceous-Eocenic rocks. The alluvial succession, 20-50 m thick, consists of unconsolidated deposits and is composed of a basal interval of sandy gravel (5-30 m thick) overlaid by a silty sand interval (10-20 $\mathrm{m}$ thick).

\subsection{Settlements and infrastructures}

The study area is a rural territory characterized by small agglomerates (villages) of few, mainly one-floor houses for a total population of about 5,500 inhabitants. The soil use is almost totally agricultural, with some sheep or goat breeding, especially along the reliefs. The area is reachable only through one main asphalted road departing from the SH27 National Road - Shkoder-Velipojë (figure 2), which connects the city of Shkoder to the Adriatic coast. At Dajç the main road splits into three branches: one going through the village and leading to the town hall and the church; one leading to the village of Samrishti; the third one going to SW to the village of Pentar. Several unpaved roads depart from the asphalted ones to reach the minor villages and the isolated houses. Many of the main buildings that can be considered strategic from a social and economic point of view are concentrated in Dajç (e.g. town hall, main church, shops and other economic activities), while the school is located in Belaj and some other important buildings are placed in Pentar I Ri.

The whole left bank of the Buna River is provided with an earth dyke (figure 2) that has been recently reinforced with concrete and groynes in the portion directly facing the chief village. There is no local connection to the right bank, since the only bridge is that one located in Shkoder, $12 \mathrm{~km}$ to NE. A river-crossing service by boat is provided, even if in a non-continuous way, by some privates on the fluvial reach between Dajç and Samrishti.

\section{Methodological approaches}

The geological risk, which is the expected value of the loss of life, injuries, damage to property and disruption to the economic activities due to a particular natural phenomenon, is expressed by a formula that links hazard, vulnerability and exposure value $(\mathrm{R}=\mathrm{H} \times \mathrm{V} \times \mathrm{E})$ (Varnes 1984). Consequently, in order to reduce the risk of natural hazards becoming disasters, it is necessary to intervene on one or more of the three components. Forasmuch as the principal geohazard of the study area is floods and earthquakes, structural interventions aimed at countering the occurrence of floods and, simultaneously, to make sure the area from earthquakes could be costly 
Table 1. Average costs for structural interventions in Albania, as reported by local authorities, and for instrumentation used in the field surveys. Instruments are valued according to the Italian market, while labour is not counted due to its low cost.

\begin{tabular}{lc}
\hline Description & Cost (k€) \\
\hline Echosounder & $1-5$ \\
Tromino & $5-10$ \\
GPS & $6-12$ \\
House renovation resisting to earthquakes & $35-40$ \\
School renovation resisting to earthquakes & $45-50$ \\
House construction resisting to earthquakes & 100 \\
Estimated damage related to 2010-2011 floods & 8,000 \\
Economic values exposed to floods and earthquakes (agriculture) & 11,000 \\
Economic values exposed to floods and earthquakes (buildings) & 15,000 \\
\hline
\end{tabular}

in terms of money and time for the considered rural community (Dajç Commune 2008; table 1). Even the intervention on the exposure value is hardly practicable. In fact the main concern faced by the local government with regard to housing is currently linked to the legalization of many buildings that have been built after 1990, illegally and in an uncontrolled way, motivated by the need for providing shelter to one's family and favoured by the lack of proper control and land management systems from the local authorities (Dajç Commune 2008). In our opinion also a significant structural intervention concerning the vulnerability may be costly in such a social context, and waiting for new and effective non-structural measures (such as laws, restrictions or surveillance and early warning systems) by the local government, we think that something more can be made regarding the increase of community coping capacity and emergency preparedness (sensu UNISDR 2010). This awareness comes from the collection of some information during the field survey relating to the economic, social and attitudinal vulnerability. These information were collected by (i) consultation of environmental requalification project involving directly or partially this area (Zaçai et al. 2010; VV.AA 2011), (ii) direct observations accompanied by local technicians and (iii) analysis of the wrong behaviour of the population during the last emergencies, observed and reported by the civil protection volunteers, like to save the cattle rather than themselves. Since vulnerability assessment is understood as a tool and a pre-condition for effective risk assessment, we concentrated our efforts exclusively in this topic. Vulnerability comprises many aspects arising from various physical, social, economic and environmental factors: in this paper we focus exclusively on the physical aspect of vulnerability, intended as the whole pre-existing conditions that are related to those characteristics and properties of the elements at risk. Therefore a flood and seismic vulnerability analysis was accurately planned and performed by means of instrumentation suitable to analyse the considered natural events in such a geomorphological context and consequently to obtain effective data with which to manage the local capacity. These devices are distinguished by the following features: (i) easy and fast data collection and processing; (ii) portability; (iii) analysis capacity of large areas in short time; (iv) low cost compared to existing equipment may be used for the same purposes; (v) worldwide diffusion; (vi) not too complicated learning with a quick training. The latter point is particularly important because we consider crucial to convey expertise and diffuse as much as possible appropriate work methodologies 
to the public administrators who will have to deal with the topic of resilience in the next future. For this purpose at the end of the work, a two-day course was also performed to expose the main results of the field survey and to begin to train the beneficiaries on local vulnerabilities, emergency behaviours and roles. In addition, after this theoretical training the local authorities and the volunteers realized the first national civil protection relief drill in Albania under the supervision of all the Italian institutions involved in this project, in order to highlight the importance of preparedness to natural disasters.

In conclusion, the methodological approach used in this area was temporarily developed and applied as follows: (i) identification of the most important geological threats; (ii) selection of the variable of the risk equation to work with: in our case we decided to evaluate the physical vulnerability since its knowledge is fundamental for enhance the community coping capacity in developing countries; (iii) selection of cost-effectiveness instrumentation and easy implementation methodologies suitable for the aims of the work; (iv) data collection and processing; and (v) representation of the results mainly by means of maps.

\section{Evaluation of the flood susceptibility}

A meticulous reconstruction of the topography of the Buna riverbed and its corresponding floodplain is essential for an effective hydraulic modelling. In particular, the extent prediction of the overflowable dykes, and consequently the areas subjected to direct floodings, inevitably depends on a careful morphological reconstruction of the perifluvial morphology, including the dykes shape and their spatial distribution, and the bathymetry of the riverbed itself. For this purpose the basic cartographic data, available at the offices of the Shkodra district and at the Geography Department of University "Luigj Gurakuqi" of Shkodra, were integrated with a DGPS survey (measurement based on Differential Global Positioning System) along the riverbanks of the Buna River and a bathymetric measurement of the riverbed using a single beam echosounder altimeter.

\subsection{Bathymetric and near-river topographic surveys}

The terrestrial topographic mapping was performed with a couple of geodetic GPS instruments (Leica SR530 devices), each of which is a 24-channel, dual-frequency GPS receiver of the highest accuracy (Leica 2002). The dual-frequency (L1/L2, fully independent), on which the measuring system is based, is essential for high-accuracy results, reduction of ionospheric influences, short rapid-static measurements and fast ambiguity resolution on the fly (Rizos 2002, 2008).

By using these devices, the operating procedures that can be applied to a topographic survey, such as required for the present work, are based both on static and dynamic modes. The first applied mode requires that both receivers simultaneously hold steady above one point in stand-alone acquisitions and uninterruptedly for an adequate time span. In such configuration, one point must be stationed over an officially known survey marker and the other over an arbitrarily materialized point in the work area to use as a reference point for the subsequent dynamic survey. These measurements, followed by a proper post-processing that puts them in direct correlation, were carried out in order to hook up a new survey point to a national 
coordinates system, and consequently to obtain a georeferenced and a functional new marker in study area. The nail that physically represents this latter point was positioned at the centre of the work area, in a little square facing the church of Dajç, ensuring its preservation through time, while the known point was found at a linear distance of about $8.5 \mathrm{~km}$ from the other, on the external walls of the Rozafa Castle in Shkoder. The acquisition time lasted approximately three hours according to the standard time normally used by the Italian Military Geographic Institute for such distances (Surace 1993).

Differently, the dynamic mode involves the use of the two receivers that are connected to each other via radio modems during the measuring phase. One of them is kept fixed over the point previously hooked up to the national coordinates system (functioning as reference in continuous measuring) and the other is moved from time to time over the points at which the altitudes and coordinates have to be measured (working as rover with fast acquisitions in separate times). The data exchange between the base station and the mobile receiver (here feasible for distances less than $2 \mathrm{~km}$ because of the antenna's range) allows each time to calculate in few measurement cycles (corresponding to few seconds) the plano-altimetric location of the rover receiver with respect to the fixed one and therefore to obtain the absolute coordinates of every visited point. This measurement procedure (called Real-Time Kinematic technique or RTK; Peyret et al. 2000), thanks to a favourable geometry of the constellation of satellites in the days of the surveys, enabled a very accurate positioning of the measured points ( $\pm 2 \mathrm{~cm}$ on average). Thus, such dynamic survey technique, proved, once again, to be very suitable for the rapid and accurate characterization of the morphological elements (both natural and anthropogenic) directly associated to the hydraulic risk along the perifluvial areas as already suggested by many authors (Higgitt \& Warburton 1999; Kinzel 2008; Morelli et al. 2012). The topographic survey, which covered a total length of $5 \mathrm{~km}$ of the left hydrographic side of the Buna river, provided a detailed map including the dyke, the access ramps, the riverbank line (with special attention to the active retreats areas), the more critical man-made works and the main river bars. The latter were also mapped on the right bank for more complete information concerning the hydraulic sections. The dyke measurement was carried out by performing a GPS survey of parallel cross sections, equally spaced $25 \mathrm{~m}$ one from each other. Since the dyke shape is similar to a trapezium, for each section four points were detected to reconstruct accurately the profile: internal and external head and foot (figure 4(a)). In the stretches where the shape of this hydraulic work was not regular (e.g. in the presence of curves) the distance between two consecutive sections was reduced in order to reconstruct the best representative morphology. However, not everywhere a similar geometrical measurement was possible because of the presence of extremely dense vegetation, which occasionally obscured the connection with the satellites or even it completely prevented access to the dyke. Consequently, in both cases, some points of the section were not acquired but they were estimated at a later stage using the nearest measured values.

The bathymetric survey was performed considering the high variability of the river flows over the seasons. Since the bathymetric survey is based on a navigation path, which is established without knowing the exact position of the most interesting riverbed morphologies, it has been carried out in the driest period (early September) in order to minimize the areas covered by the water for the benefit of the terrestrial mapping (figure 4(b)). Moreover in such hydrodynamic condition a little boat is more governable and the turbidity is reduced. The morphological data of the wet 


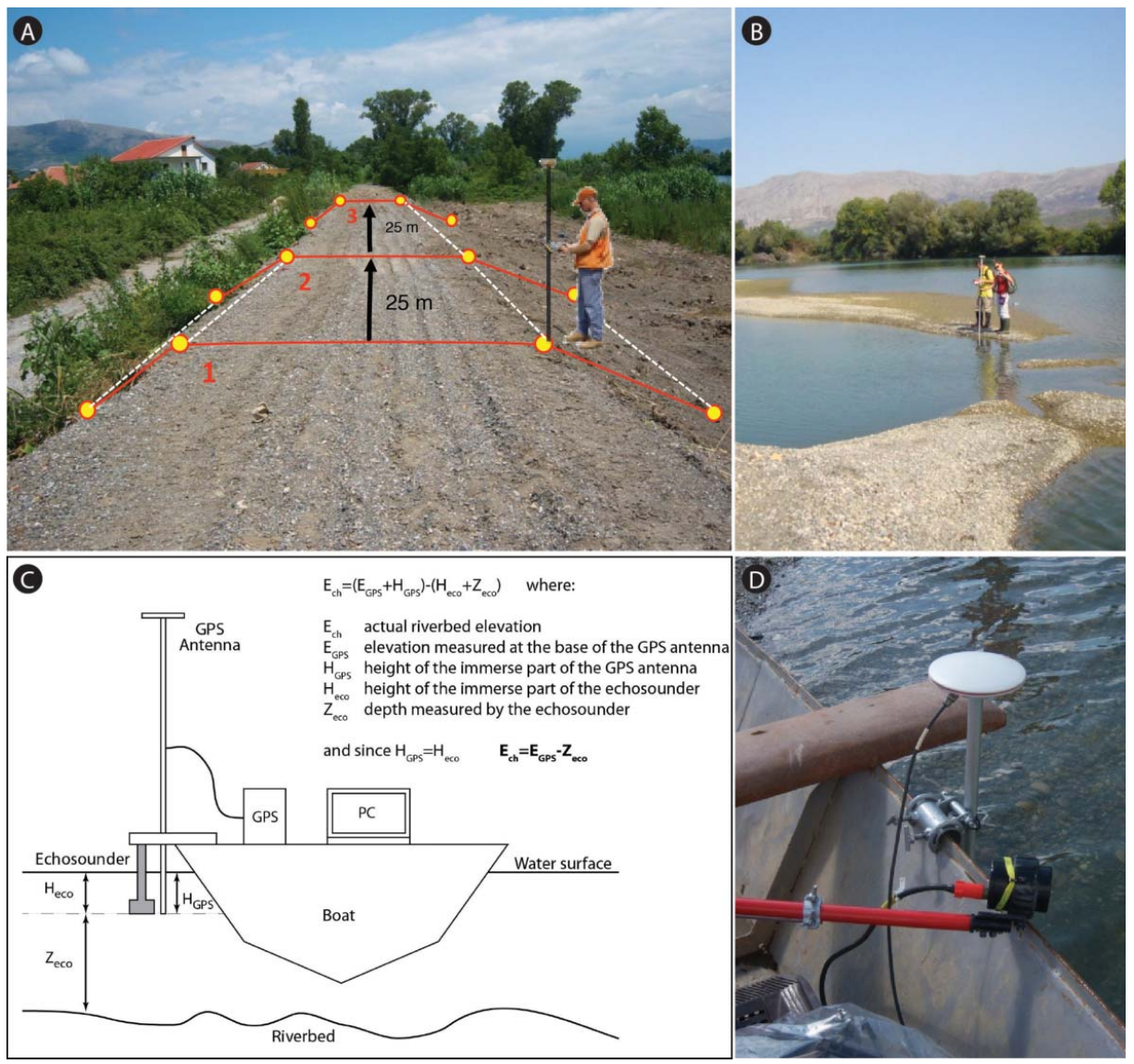

Figure 4. GPS survey of the dyke $(a)$ and river bars $(b)$. Sketch $(c)$ and picture $(d)$ showing the tools used for the bathymetric survey.

perimeter were collected combining the GPS technology in Real-Time Kinematic mode with an echosounder altimeter, both integral with the hull of the boat (Mastin $\&$ Fossness 2008; figures 4(c) and $(d)$ ). By means of the Neptune ${ }^{\circledR}$ software installed on the laptop to which the aforesaid instruments were connected, the data concerning the geographic location and depth were simultaneously displayed and collected in real time. The GPS device is the same as for the terrestrial survey although with a different setting regarding the format of the output data. Whereas the echosounder altimeter (Ocean Tools - MA500 device; figure 4(d)) is a measuring device which is characterized by an operating frequency of $500 \mathrm{kHz}$, a field of view of $6^{\circ}$, a measuring range of $0.5-30 \mathrm{~m}$ and $1 \mathrm{~mm}$ resolution (Nolan \& Toal 2008). Nevertheless it is not able to rectify any defects caused by pitching or rolling of the boat or any inaccuracies related to the water turbidity or growth of vegetation on the bottom. These adverse effects should be adequately considered whenever a measurement campaign is planned, as it was done in this specific case. So, from a preliminary study of this watercourse, based on the examination of orthophotos, a series of hydraulic sections were identified as route for the navigation, in order to cover all the $5 \mathrm{~km}$ of the studied river stretch. Their number and spacing was congruent with the final purpose of a 
detailed mapping. Moreover in order to obtain a digital terrain model of the riverbed, which could be representative of the real morphology, the distance between consecutive sections was reduced where the course appeared more irregular (e.g. greater sinuosity, presence of tributaries or bifurcation of the main channel). Despite the utmost care in the choice of sections it was not possible to follow all the established segments during the survey, since the low water level highlighted some obstacles for navigation. Thirty-four transversal sections were actually followed and by means of these a high degree of detail was still maintained. In addition also the longitudinal reaches between sections were measured and recorded obtaining on the whole a

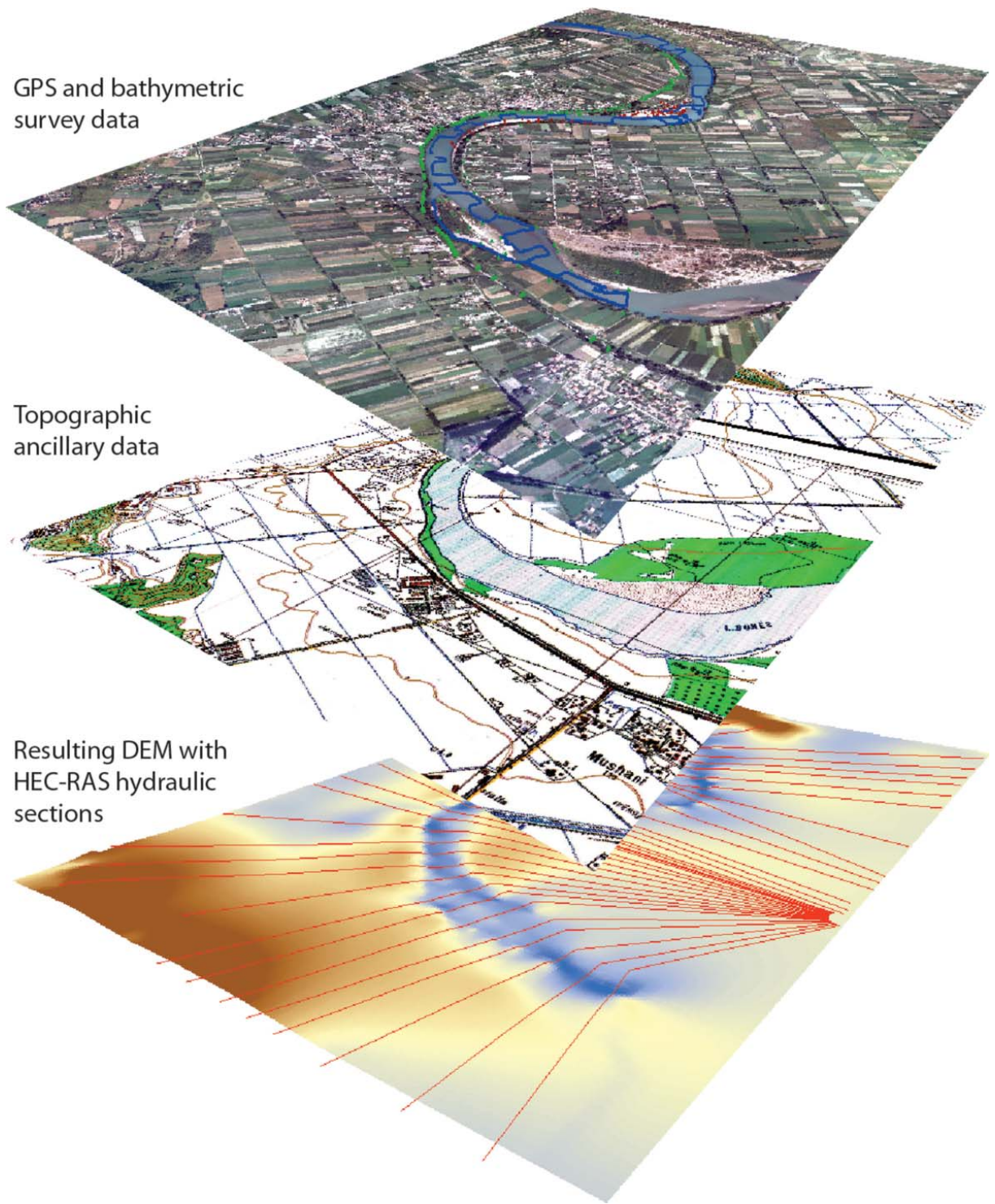

Figure 5. Integration of all the data deriving from GPS and bathymetric surveys with topographic ancillary ones, resulting in a Digital Elevation Model (DEM). 
dense point cloud along the main channel (figure 5). Finally, where the small depth of the riverbed did not allow the navigation the density of the measured points was integrated using only the hand-held GPS device (figure 4(b)).

As concerns the terrestrial topographic mapping, the GPS hardware allowed to store the RTK data on a PCMCIA card in a Leika proprietary format called raw data. By their processing with the Leica GeoOffice software an output file in text format was edited, within which the geographic coordinates of the measured points are recorded according to the reference system WGS84 (ETRF89) and their corresponding ellipsoidal heights are annotated. Subsequently by using the VERTO software the geographic coordinates were converted into projected coordinates whose cartographic reference system is defined as follows: UTM-WGS84 (the study area falls within zone $34 \mathrm{~N}$ ). In addition a mathematical transformation was applied to the height values in order to move from ellipsoidal to orthometric values. At this point these data were saved in ASCII format and imported into ArcGIS ${ }^{\circledR}$ software to create a basic working project on which to base the reconstruction of the terrain model (figure 5).

In relation to the bathymetric data, the NMEA messages (defined by strings in GGA format) coming from the GPS-RTK measuring were immediately combined by the Neptune ${ }^{\circledR}$ software with the depth values calculated by the echosounder altimeter. In such way the measured coordinates and elevations were obtained for a vast series of points on the surface of the riverbed. Finally such coordinates were converted into the projected system UTM-WGS84 and the heights were transferred from ellipsoidal to orthometric values, as in the terrestrial measuring. All the converted data were consequently imported into the previously created ArcGIS ${ }^{\circledR}$ project through a file in ASCII format. The mapped points were combined with elevation data deriving from the digitization of contour lines and spot heights of the study area available base map at 1:10,000 scale. The data integration was performed by means of the 3D Analyst tool (Create/Modify TIN $\rightarrow$ Create TIN from features) in order to create a digital elevation model (DEM; figure 5) in which all the most useful topographic information are included for a realistic hydraulic modelling.

\subsection{Hydraulic and flood modelling}

The hydraulic modelling was carried out by means of HEC-RAS (Hydrologic Engineering Center - River Analysis System), a freeware software designed to perform one-dimensional (1D) hydraulic calculations for a full network of natural and anthropic channels (Stratobërdha et al. 2008; Tetra 2009; Brunner 2010a, 2010b), and using its ArcGIS $^{\circledR}$ interfacing tool HEC-GeoRAS (Tate \& Maidment 1999; Casas et al. 2006; Ackerman 2009). The software allows to perform four different analyses: (i) steady flow water surface profile computations, (ii) unsteady flow simulation, (iii) movable boundary sediment transport computations and (iv) water quality analysis. Basing on the purposes of the work, only the steady and the unsteady flow analyses were carried out. Both analyses allow to model water surface profiles with subcritical, supercritical or mixed flow regime: the first method solves the 1D energy equation by means of an iterative procedure called standard step method (Brunner 2010a, 2010b), while the second solves the 1D Saint Venant equation adapted by the Barkau's UNET model (Barkau 1992) by means of an implicit finite difference method. 


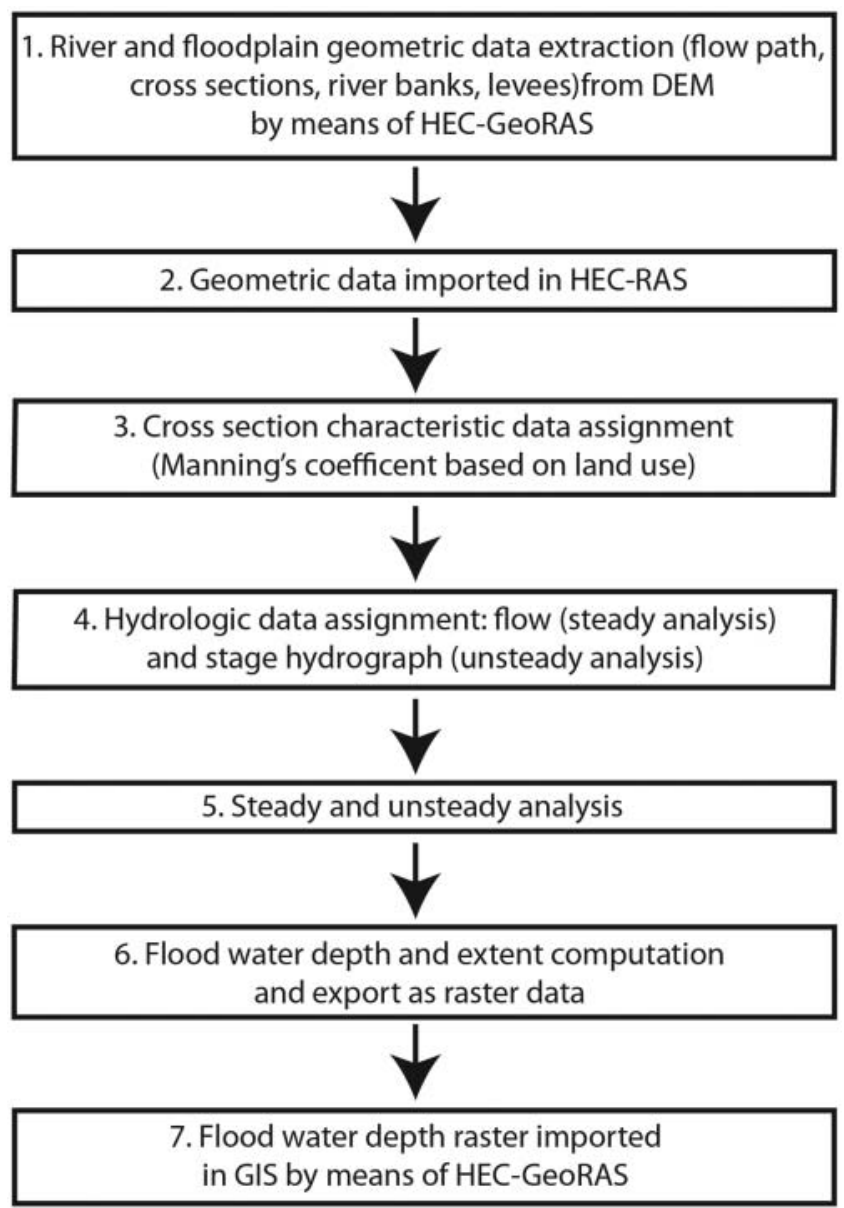

Figure 6. Workflow for the hydraulic modelling with HEC-RAS.

The hydraulic and flood model can be summarized in seven steps, as sketched in figure 6. Initially, 39 cross sections were accurately extracted from the collected topographical data of the studied river reach (figure 5). The roughness coefficients of each cross section, which represent the surface's resistance to flow and are integral parameters for calculating water depth, were estimated by comparing the actual land use with the tabulated Manning's $n$ values (figure 7 and table 2; Chow 1959; Casas et al. 2006; Brunner 2010b). The land use was obtained by aerial photo interpretation and field observations, so that each section was portioned into several segments $(\min =3$; MAX $=8$ ) with homogeneous roughness. As concerns the steady simulation the water surface profiles were calculated for the mean annual and monthly flows (Pano \& Avdyli 2009; Zaçaj et al. 2010) and for a 3,500 $\mathrm{m}^{3} / \mathrm{s}$ flow, like the one estimated for the December 2010 flood peak by the local administrations. For the latter analysis a mixed flow regime was defined, while for the mean flow analysis a subcritical one was used. The normal depth, given as the river stretch slope (1.25E-04) and calculated basing on the GPS survey of the water free surface, was established as boundary condition, for all the analyses. On the other hand, the stage hydrograph of the Dajç 


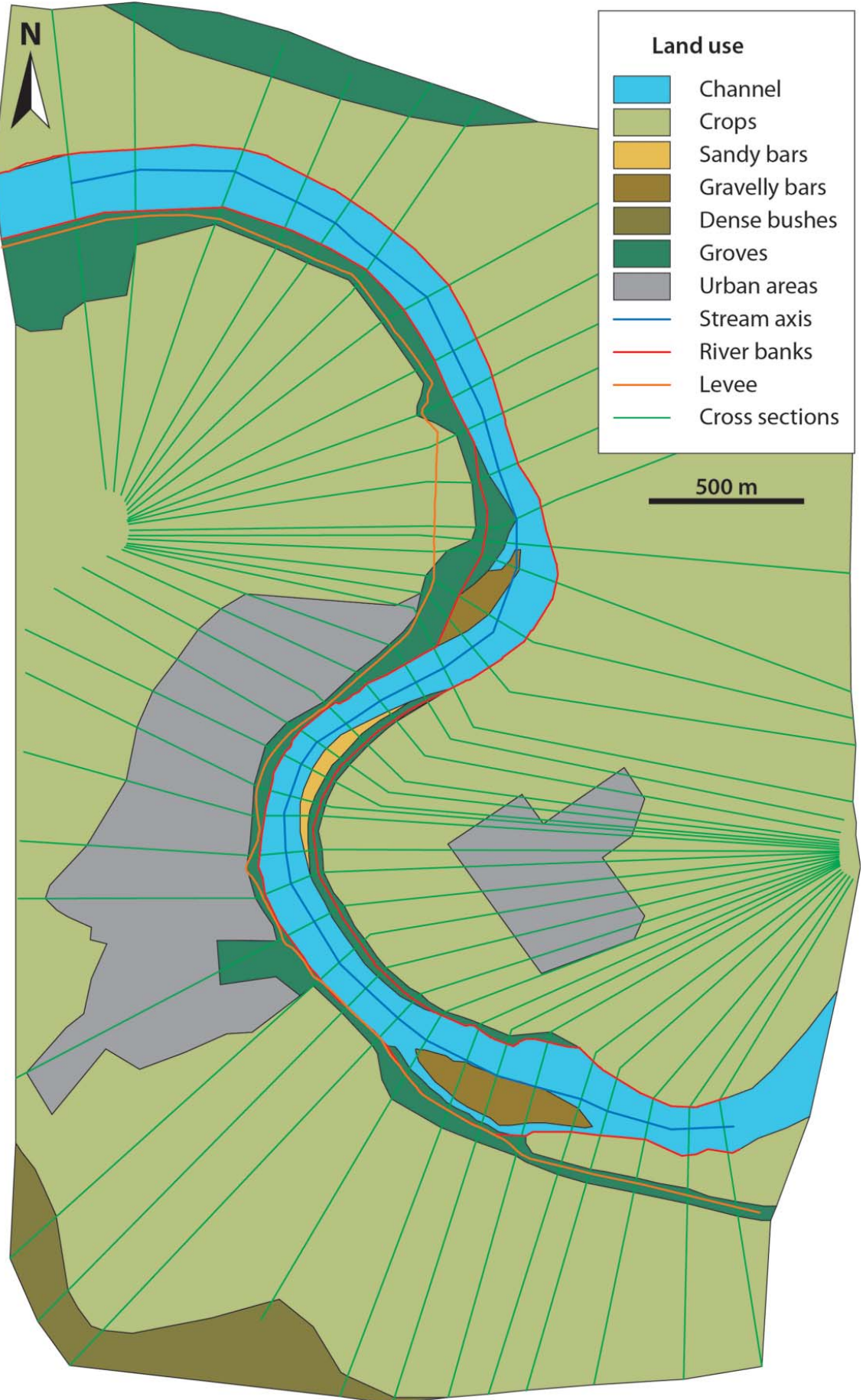

Figure 7. Geometric input data for the HEC-RAS model: river boundaries, cross sections and land use for Manning's roughness coefficient classification. 
Table 2. Manning's $n$ coefficients for the different land uses reported in figure 7 .

\begin{tabular}{lc}
\hline Description & Value \\
\hline Channel (sandy, densely vegetated) & 0.035 \\
Crops & $0.040-0.050$ \\
Sandy bars & 0.025 \\
Gravelly bars (with scattered bushes) & $0.070-0.080$ \\
Dense bushes & 0.100 \\
Groves & 0.080 \\
Urban areas & 0.080 \\
\hline
\end{tabular}
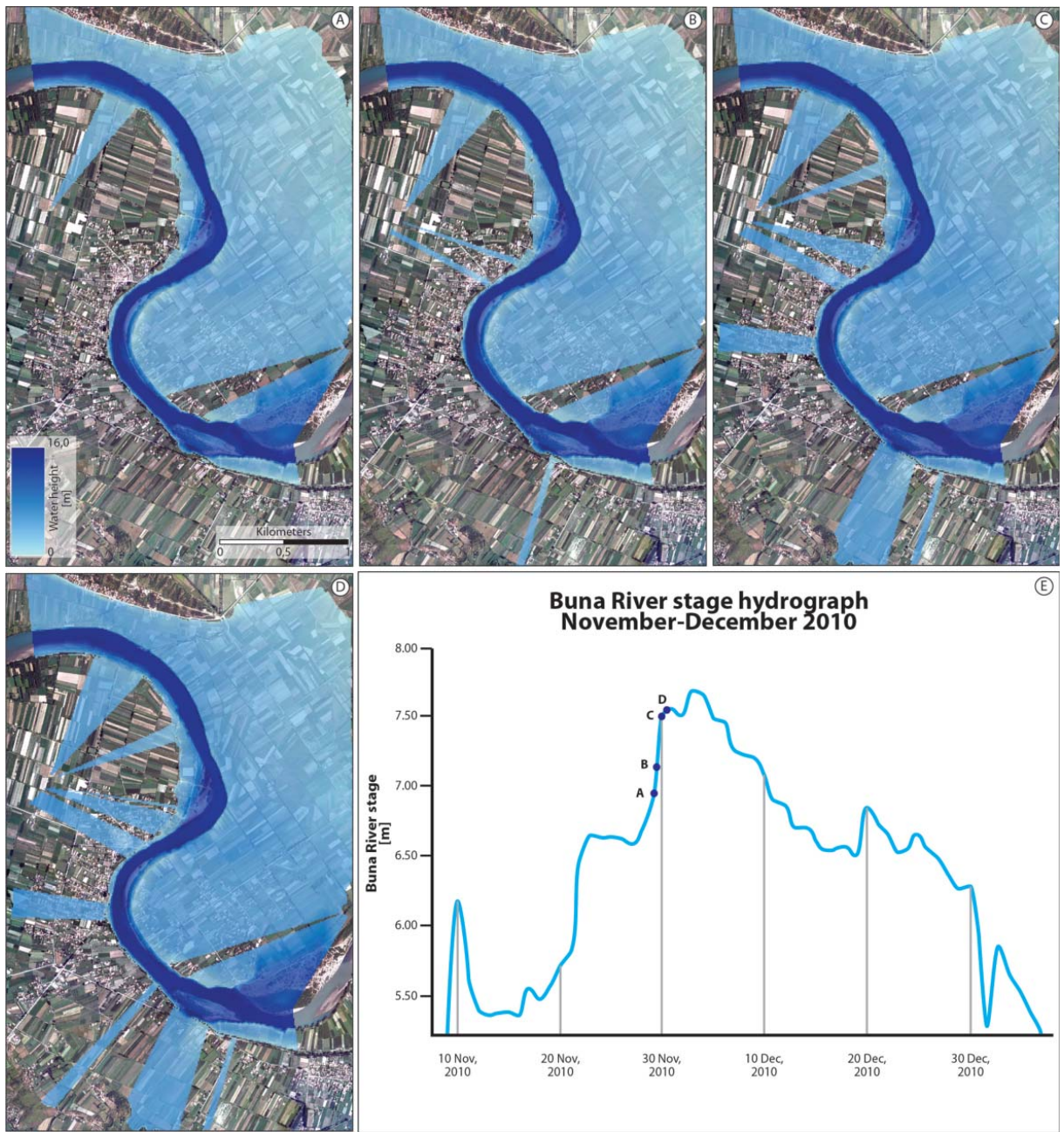

Figure 8. Maps showing unsteady flow simulation results in terms of water height on: $(a)$ November 29, 2010, 12:00 PM; (b) November 30, 2010, 08:00 AM; (c) November 30, 2010, 12:00 PM; (d) December 1, 2010, 08:00 AM. (e) Stage hydrograph of the Buna River for the computed period (water heights were measured at the Dajç hydrographic station). 
hydrometric station (N: $19^{\circ} 25^{\prime}$, E: $41^{\circ} 59^{\prime}$; figure $2(a)$ ) covering the period August 1 , 2008 to November 30, 2011 was used as boundary condition in the unsteady flow analysis. In this case a mixed flow regime was defined; the upper stream boundary condition was the stage hydrograph, while the downstream one was the river stretch slope. The computational interval was set at one hour, while the hydrograph output interval was set at eight hours.

The steady and unsteady hydraulic and flood analyses confirm that the right bank is more prone to flooding, being not protected by dykes. On the left bank dykes are firstly overflowed near Samrishti (figure 8), where their height is the lowest ( $h=6 \mathrm{~m}$ a.s.1.), then near Dajç ( $h=7 \mathrm{~m}$ a.s.1.) and finally near Mushani $(h=7 \mathrm{~m}$ a.s.1.), where river terraces completely lack (figure 8). As expected, the lowered areas are those that are firstly drowned. Moreover the flood peak characteristics considerably affect the height of overflowing. The hydraulic and flood analysis results agree with the real data: wet surfaces correspond to those reported in literature (Zaçaj et al. 2010) and by the local administrations. The results of the steady flow analysis, carried out with a $3,500 \mathrm{~m}^{3} / \mathrm{s}$ flow, and the unsteady flow analysis results of the December 6, 2010 event, when the water height was the highest recorded $(7.68 \mathrm{~m})$, are also comparable.

\section{Seismic vulnerability assessment of strategic buildings}

The seismic vulnerability assessment of the existing buildings is important to understand the soil-structure interaction effects (Stewart \& Fenves 1998): recent studies have shown that the Horizontal to Vertical Spectral Ratio (HVSR) method (Nakamura 1989) is able to detect the fundamental vibration modes of the buildings (Mucciarelli et al. 2001; Gallipoli et al. 2004). To process the environmental noise traces according to the H/V technique means identifying the origin (natural or anthropogenic) of the $\mathrm{H} / \mathrm{V}$ peaks and consequently the ground or building resonant frequency.

\subsection{Seismic-noise survey}

According to the local administration, three strategic buildings were selected to perform the seismic vulnerability analysis: the Dajç town hall (figure $9(a)$ ), the Dajç main church (figure $9(b)$ ) and the "Lucë Agraja" secondary school in Belaj village (figure $9(d)$ ). These buildings were chosen because during the 2010/2011 floods they served both as operating centres for the crisis management and as shelter for displaced people. Moreover free-field measurements of ambient noise were carried out in an open area close to Pentar (figure 2), a raised site chosen as a gathering point in case of emergency. Finally measurements on exposed bedrock were performed in Pentar and Belaj (figure 2). In order to characterize the main frequencies of the existing buildings, microtremors measurements were carried out at each floor of the above-mentioned structures and free-field measures were performed as far as possible from them, in order to avoid their influence and not on cement, concrete or asphalt (Gallipoli et al. 2004; Castellaro \& Mulargia 2009; Ditommaso et al. 2010). The seismic noise was recorded by means of two Tromino ${ }^{\circledR}$, the all-in-one compact 3-directional 24-bit digital tromometers by Micromed (maximum portability: $1 \mathrm{dm}^{3}$ volume and $1 \mathrm{~kg}$ weight; figure 9(c)) (Castellaro \& Mulargia 2009; Ditommaso et al. 2010). According to the Italian Civil Protection guide lines about microtremors measurements, these instruments were chosen both for their ease of use and for the very small 

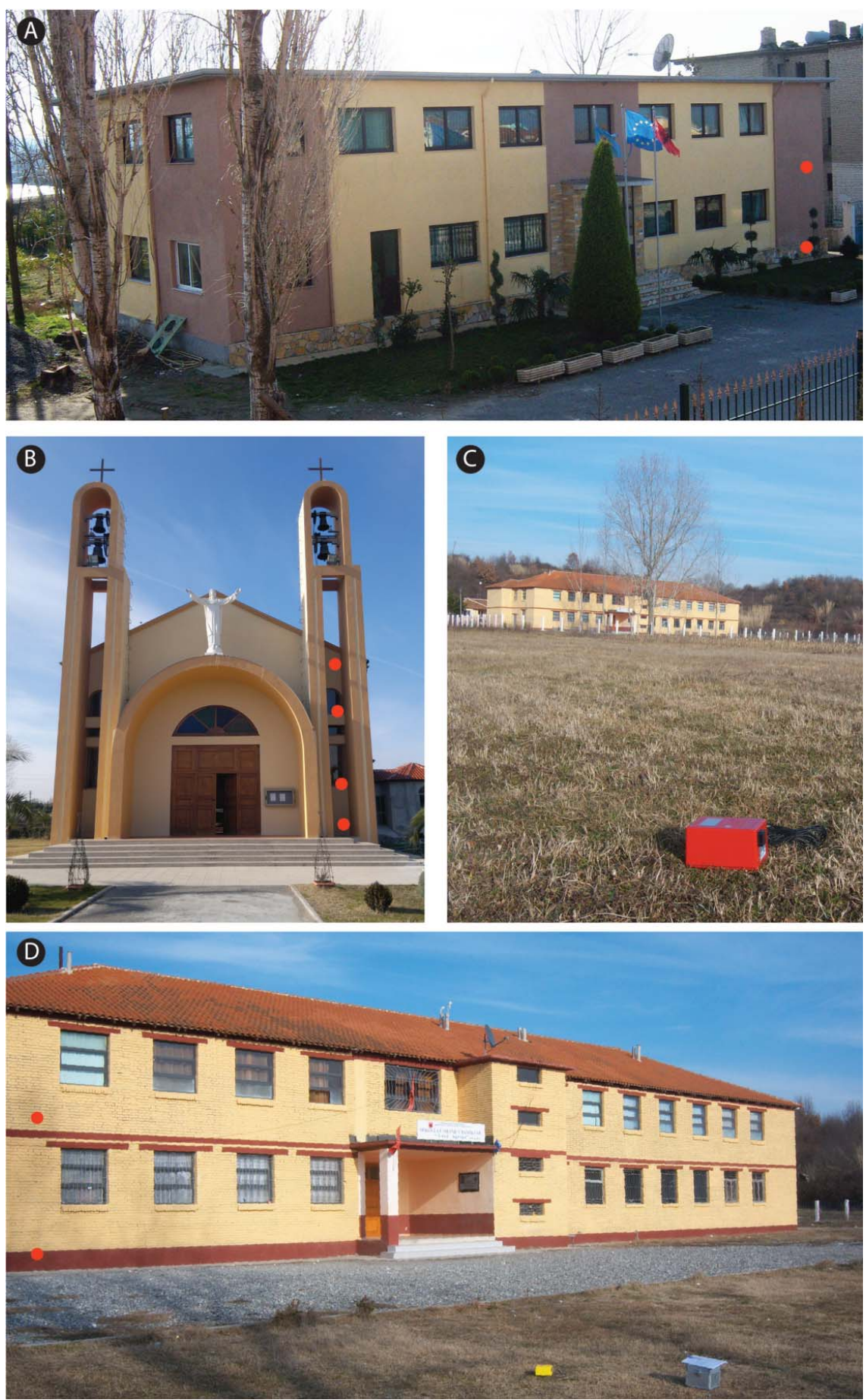

Figure 9. Photos showing some of the locations where seismic noise measures were performed: (a) Dajç town hall; (b) Dajç church; $(c)$ free-field measure near the Belaj school; $(d)$ Belaj school. The red dots indicate the measuring points within the buildings. To view this figure in colour, please see the online version of the journal. 
size and the absence of connection cables between geophones, seismograph and datalogger, which considerably reduces the noise induced by instrumentation on the measures of seismic noise.

Outside of the buildings the instruments were aligned to the geographical north and left to acquire for 20 minutes, while inside the instrumental north was aligned to the minor axis of the building and each measurement run for 10 minutes. The instrument-soil coupling was obtained using the pins set supplied with the instrument or placing it directly on the soil (Ditommaso et al. 2010). The sampling rate was $128 \mathrm{~Hz}$.

\subsection{Seismic data analysis and results}

The data analysis was carried out using the Grilla ${ }^{\circledR}$ software (by Micromed), that implements the guidelines for processing ambient vibration data according to the HVSR technique (Nakamura 1989; SESAME 2004). For each site, as first approximation, the whole trace was subdivided into non-overlapping windows of 20 seconds and each window was: (i) analysed to keep the most stationary parts of the signal avoiding the transient; (ii) fast Fourier transformed and (iii) smoothed with triangular windows with a width equal to $10 \%$ of the central frequency. The directionality degree of each spectral peak was evaluated through directional $\mathrm{H} / \mathrm{V}$ analysis with an angular step of $10^{\circ}$ (Del Gaudio et al. 2008). Later, some parameters, like the analysis frequency range or the smooth-window width, were changed basing on the first outcomes in order to improve the analysis results.

It is important to remember that the single component spectra (NS, EW and Z) are the averages computed on each single direction, for each analysis window, while the final $\mathrm{H} / \mathrm{V}$ is the ratio between the Euclidean average of the horizontal component spectra (EW and NS) and the vertical one (Z) for each window (Castellaro \& Mulargia 2009). In the average $\mathrm{H} / \mathrm{V}$ spectrum (figures $10(a),(e),(g)$, and $(i)$ ) the black lines enclose the confidence interval $(\Delta(\mathrm{H} / \mathrm{V}))$ of the $\mathrm{H} / \mathrm{V}$ curve: because of the properties of the errors, that are always additive, the $\mathrm{H} / \mathrm{V}$ confidence interval is narrow if the confidence intervals of the single components $(\Delta \mathrm{H}$ and $\Delta \mathrm{V})$ are narrow (Castellaro $\&$ Mulargia 2009). This is why the transients were removed carefully during the first signal analysis. If $f_{0 i}$ is the central frequency of the $i$ th peak in the spectral components figures, the natural peaks are clearly marked by an "eye-shaped" detachment of the horizontal components from the vertical one centred in $f_{0 i}$ (SESAME 2004) and by a $\mathrm{H} / \mathrm{V}$ curve amplitude $<1$ around $2 f_{0 i}$ (Castellaro \& Mulargia 2009).

If the sedimentary cover above the rocky substrate is a homogeneous horizontal layer over a half-space, the resonance fundamental frequency $\left(f_{0}\right)$ is given by the equation

$$
f_{0}=V_{\mathrm{s}} / 4 h
$$

where $V_{\mathrm{s}}$ is the S-wave velocity of the coverage and $h$ is its thickness.

In order to identify the fundamental frequencies of the buildings, the internal measurements were referred at the one got outside the building (Ditommaso et al. 2010).

The Dajç town hall building is a two-floor structure (figure $9(a)$ ), rectangularshaped, with side-lengths of about $25 \times 10 \mathrm{~m}$, build with reinforced concrete and bricks. Simultaneous microtremors measurements were carried out at the ground and the first floor on the western side of the structure. Two free-field measurements, whose 

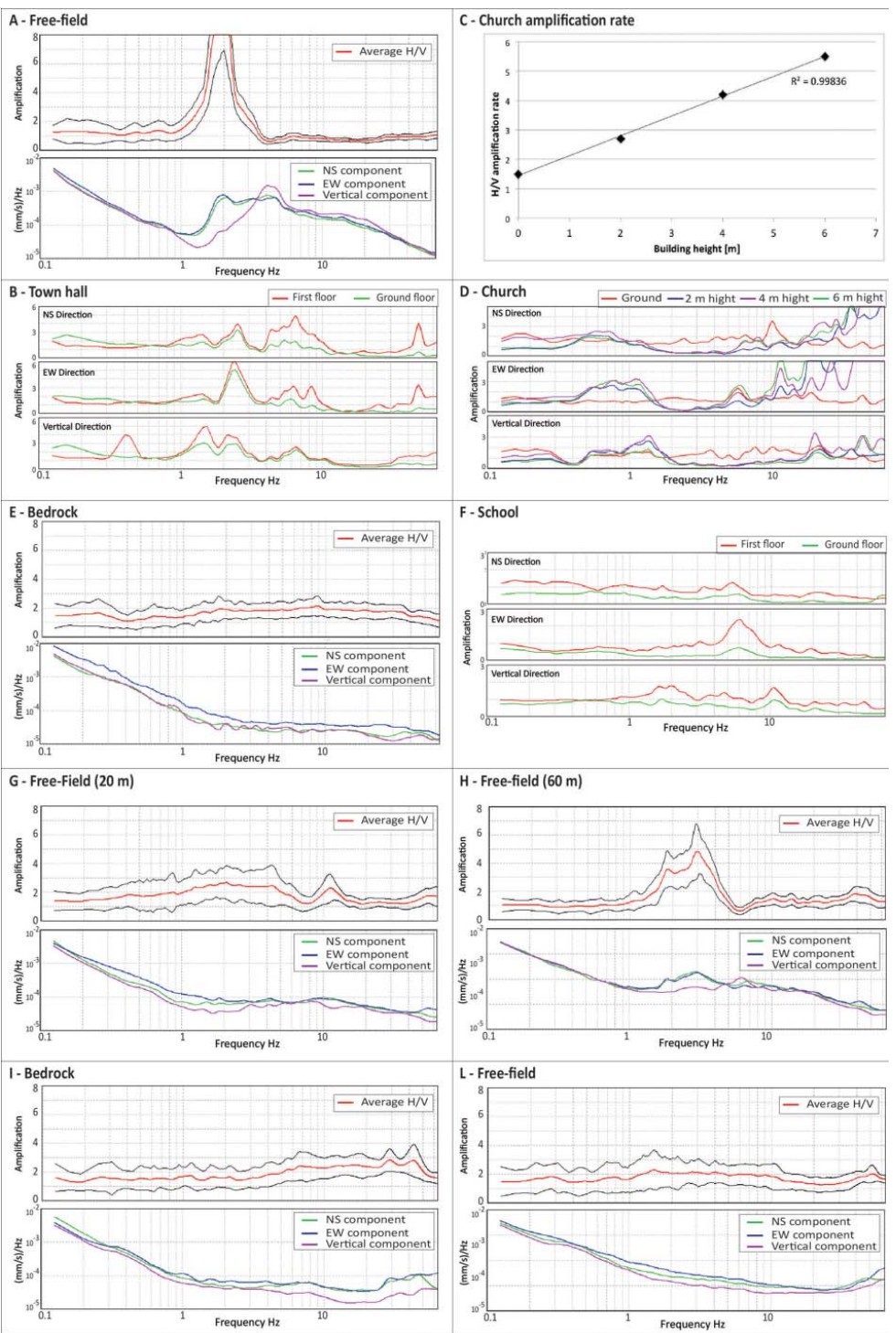

Figure 10. (a) The H/V spectral ratio and the three component spectra of the free-field measurement carried out in the church garden (in front of the town hall - Dajc village) and employed as reference for the building vibration analysis. (b) The town hall $\mathrm{H}_{0} / \mathrm{H}_{i}$ spectra. (c) The church amplification rate. (d) The church $\mathrm{H}_{0} / \mathrm{H}_{i}$ spectra. (e) The $\mathrm{H} / \mathrm{V}$ spectral ratio and the three component spectra of the measurement carried out on the outcropping bedrock $200 \mathrm{~m}$ away from the school (Belaj village). $(f)$ The school $\mathrm{H}_{0} / \mathrm{H}_{i}$ spectra. $(g)$ and $(h)$ The $\mathrm{H} / \mathrm{V}$ spectral ratio and the three component spectra of the two free-field measurements carried out 20 and $60 \mathrm{~m}$, respectively, away from the school. (i) The H/V spectral ratio and the three component spectra of the measurement carried out on the outcropping bedrock near the Pentar village. (l) The H/V spectral ratio and the three component spectra of the free-field measurement carried out on the field that was employed as a gathering place during the last emergency. 
results are comparable, were carried out in the adjacent garden. The $\mathrm{H} / \mathrm{V}$ spectral ratios of the free-field measurements show a natural peak at $1.88-2 \mathrm{~Hz}$ (figure $10(a)$ ). To evaluate the town hall seismic vulnerability, the ratios between the internal measurements and the two free-field measurements were calculated. These ratios are comparable and the results of the ratio with the nearest free-field measure are shown in figure $10(b)$ : the $2.5 \mathrm{~Hz}$ peak can be correlated to the soil effect on the structure, while the $6.5 \mathrm{~Hz}$ peak, clearly visible on all the components, and the $8.2 \mathrm{~Hz}$ peak, visible on the EW direction, are respectively the first and second vibrating mode of the structure (Ditommaso et al. 2010). The ratiobetween the frequency of the soil and the buildings first vibrating mode (Clinton et al. 2006) is in the range 0.29-0.31.

The Dajç church (figure 9(b)), a reinforced concrete and bricks building, is quite recent: its aisle is about $35 \mathrm{~m}$ and the transepts are about $20 \mathrm{~m}$. During the 2010-2011 floods, as reported by the local authorities, the church suffered differential settlements between the aisle and the transepts. Because of the church shape, as well as considering the aforementioned information, the internal measurements were performed in three different places: (i) at four different heights near the east main door (figure 9(b)); (ii) at two different heights in the south transept and (iii) at two different heights in the new sacristy, built against the north transept in January 2012. The same free-field measurements used for the town hall spectral ratio were used, since the church is so close to the external measuring point as the town hall is. Regarding the inside measures, only the results of those performed on the eastern side are here reported, because they resulted more significant: the $6 \mathrm{~Hz}$ peak, clearly visible on the EW direction, and the $8 \mathrm{~Hz}$ peak, visible on the NS direction (figure $10(d)$ ), represent the first and second vibrating mode of the structure respectively (Ditommaso et al. 2010). Figure 10(c) shows that the amplification increases linearly with the height (Gallipoli et al. 2004). The ratio between the soil frequency and the building's first vibration frequency (Clinton et al. 2006) is $0.31-0.33$.

The Belaj school (figures $9(c)$ and $(d)$ ) is a two-floor building, rectangular-shaped, with side-lengths of about $45 \times 15 \mathrm{~m}$, build with reinforced concrete and bricks. It suffered extensive damages during the 2010-2011 floods, so that the ground floor classrooms are presently unusable. Simultaneous microtremors measurements were carried out at the ground and the first floor on the eastern side of the structure. Four free-field measurements were carried out: two on the exposed bedrock at 120 and $200 \mathrm{~m}$ from the school and two on the field in front of the school at 20 and $60 \mathrm{~m}$. The $\mathrm{H} / \mathrm{V}$ spectral ratio of the measurements carried out on the bedrock, as expected (Field \& Jacob 1995; Lachet et al. 1996), is flat with an amplification value of 1 (figure 10(e)); the $\mathrm{H} / \mathrm{V}$ spectral ratios of the free-field measurement carried out $20 \mathrm{~m}$ far from the school show a natural peak at $11.25 \mathrm{~Hz}$, while the other shows a natural peak at $2.97 \mathrm{~Hz}$ (figures $10(g)$ and $(h)$ ).

The ratios between the inside measurements and the two free-field measurements were calculated to evaluate the school seismic vulnerability. These ratios are comparable and the ratio with the nearest free-field measure is shown in figure 10(f): the $6 \mathrm{~Hz}$ peak clearly visible on the EW direction is the first vibrating mode of the structure (Ditommaso et al. 2010). The ratio between the frequency of the soil and the first vibrating mode of the building (Clinton et al. 2006) is 0.49 .

In Pentar two measurements were carried out: one on the exposed bedrock and one on a field used as a gathering point during the last floods: both the H/V spectral ratios are flat and equal to 1 (figures $10(i)-(l)$ ). 


\section{Discussion}

The studied area is very prone to flooding, due to a combination of natural (geomorphological, hydraulic) and anthropogenic (dams management, dykes location and morphology) causes. In the last ten years at least three main flood events occurred in the area, dramatically affecting the population: (i) many businesses were closed and many people were out of work; (ii) surface waters were polluted due to the uncontrolled circulation of waste water; (iii) schools remained closed for a few weeks; (iv) agriculture was strongly damaged often with the loss of the entire annual production (table 1). The local authorities are thus in need of a tool capable of predicting, with a certain precision, where the dykes are going to be firstly overflowed with a given discharge for the Buna River.

The selected approach for the hydraulic vulnerability evaluation is really cost effective, since it is based on an open source software (HEC-RAS) integrated with a common ArcGIS $^{\circledR}$ platform. The required input data (hydrological data, river bathymetry, banks morphology and land use) are already owned or easily achievable for the local authorities. To test the methodology we processed the data relative to the last flooding event and verified whereas the modelling results were comparable with the real observed scenario. The unsteady flow analysis results obtained using the hydrometric data for the considered flood peaks (December 6, 2010 and January 13, 2011) accurately reproduce the real scenarios for those days in terms of dykes overflowing, as shown by satellite images (ENVISAT ASTAR and TerraSAR-X; figures 11 and 12) elaborated and made available as free data by the Center for Satellite Based Crisis Information. Moreover, as shown in figure 12, the results obtained by the steady flow simulation, using as input datum a discharge value of $3,500 \mathrm{~m}^{3} / \mathrm{s}$, and those deriving from the unsteady flow simulation, using the flood hydrograph for the same event, are comparable. In case a single surge event simulation is needed (i.e. a sudden opening of the dam), the steady flow analysis demonstrates to be the most effective tool in terms of required input data, computational time and results. This kind of simulation can be extremely useful as a forecasting tool to predict the dykes overflowing locations for a given discharge. The unsteady flow analysis is recommended to evaluate critical values for hydrometric heights and estimate alert thresholds.

The study area resides in a seismically active area too. A detailed seismic zonation was besides the aims of the project, thus a rapid method to establish the seismic vulnerability of strategic edifices was implemented. This methodology is based on the usage of relatively simple and low cost instruments (Tromino ${ }^{\circledR}$ ), whose major skill is its high portability. This kind of approach, based on the HVSR Nakamura's technique (Nakamura 1989), is widely reported in literature (e.g. Mucciarelli et al. 2001; Gallipoli et al. 2004; Sesame 2004; Del Gaudio et al. 2008; Castellaro \& Mulargia 2009; Ditommaso et al. 2010). With reference to equation (1), given the $f_{0}$ value for the studied site and deducing the $V_{\mathrm{S}}$ values from local geology, it is possible to constrain the $\mathrm{H} / \mathrm{V}$ curves and perform a theoretical fit in terms of $V_{\mathrm{s}}$ to obtain the approximation of the stratigraphy of the first meters (Fäh et al. 2001; Arai \& Tokimatsu 2004; Castellaro \& Mulargia 2009). This fitting was carried out by means of the Grilla ${ }^{\circledR}$ software and the $V_{\mathrm{s}}$ were drawn from the geological map of the Dajç municipality (Zaçaj et al. 2010). Therefore the theoretical fit in terms of $V_{\mathrm{s}}$ of the two free-field measurements carried out in front of the Dajç town hall allowed to detect the first impedance contrast between a sandy gravel layer $\left(V_{\mathrm{s}}=198 \mathrm{~m} / \mathrm{s}, \gamma=2 \mathrm{t} / \mathrm{m}^{3}\right)$ and the fractured bedrock $\left(V_{\mathrm{s}}=570 \mathrm{~m} / \mathrm{s}, \gamma=2.3 \mathrm{t} / \mathrm{m}^{3}\right)$ at about $30-35 \mathrm{~m}$. In Belaj 

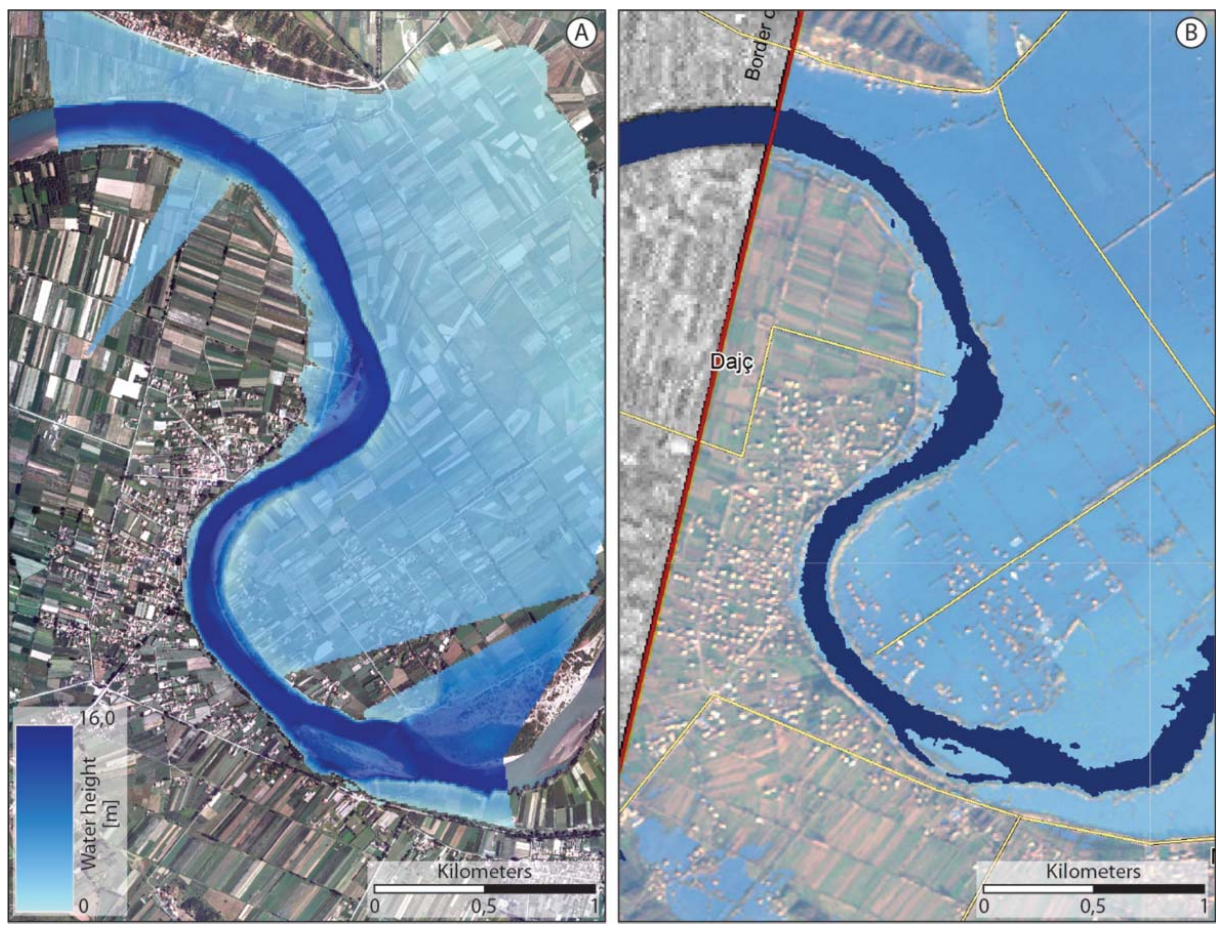

Figure 11. Maps showing: $(a)$ the unsteady flow simulation results in terms of water height on January 10, 2010, 12:00 PM and $(b)$ the January 10, 2010 ENVISAT ASAR satellite flood maps (produced by ZKI, the Center for Satellite Based Crisis Information). The software generates a 1D output (locations of dykes overflowing) and it does not model the distribution of water in the floodplain: this is why the real scenario is locally differing from the modelling results.
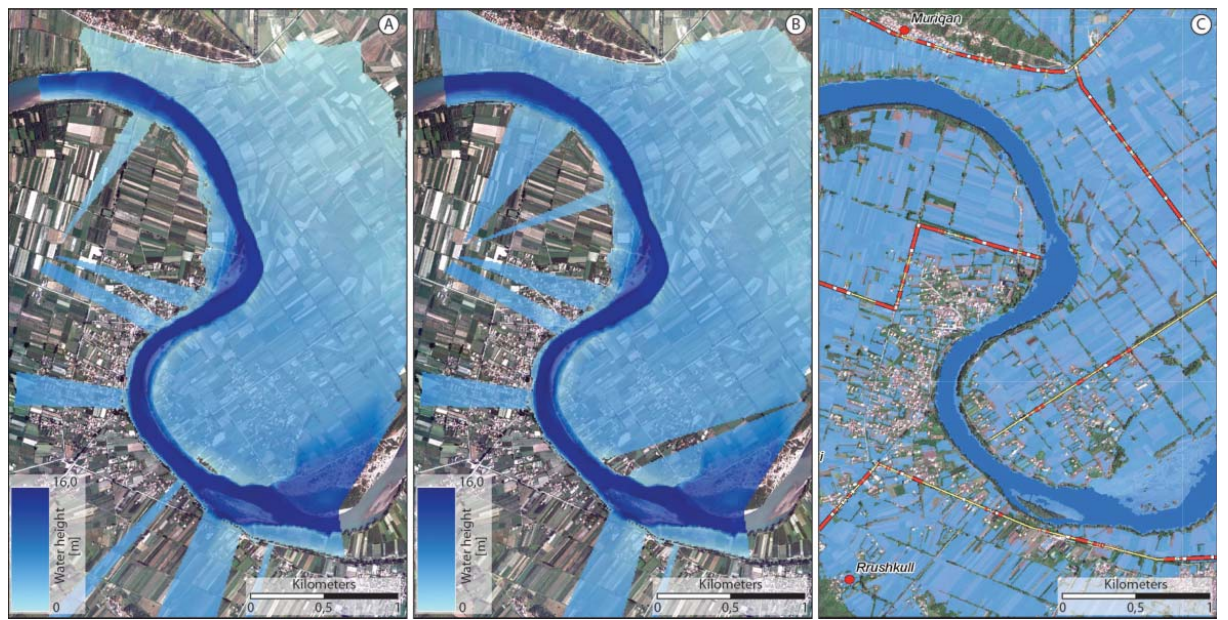

Figure 12. Maps showing: (a) the $3,500 \mathrm{~m}^{3} / \mathrm{s}$ steady flow simulation results in terms of water height; $(b)$ the unsteady flow simulation results in terms of water height on December 6, 2010, 12:00 PM; (c) the December 6, 2010 TerraSAR-X satellite flood maps (produced by ZKI, the Center for Satellite Based Crisis Information). The software generates a 1D output (locations of dykes overflowing) and it does not model the distribution of water in the floodplain: this is why the real scenario is locally differing from the modelling results. 
the first impedance contrast depth between a layer of detrital cover due to the bedrock alteration $\left(\mathrm{V}_{\mathrm{s}}=170-200 \mathrm{~m} / \mathrm{s}, \gamma=1.2 \mathrm{t} / \mathrm{m}^{3}\right)$ and the fractured bedrock $\left(V_{\mathrm{s}}=\right.$ $400 \mathrm{~m} / \mathrm{s}, \gamma=2.3 \mathrm{t} / \mathrm{m}^{3}$ ) increases, moving away from school, from 5 to $15 \mathrm{~m}$ depth. Both the sites can be thus affected by amplification phenomena due to the presence of a layer with low $\mathrm{V}_{\mathrm{S}}$ velocity over the seismic bedrock. On the other hand, in Pentar the flat $\mathrm{H} / \mathrm{V}$ response (figure $10(l)$ ) means that the field is not subject to amplification phenomena.

Very damaging resonance effects may arise if the frequency of the building is similar to that of the soil. Moreover the buildings dynamic behaviour is determined by several external factors on very different timescales: the observed decrease in fundamental frequencies can be correlated with weather, earthquake history, and building usage (Gallipoli et al. 2004; Clinton et al. 2006). Taking into account equation (1) and that the building resonance frequency is proportional to the structure height according to the well-known rule of thumb

$$
f_{B}=10 \mathrm{~Hz} / n
$$

where $n$ is the building floors number, it can be stated that the structure, at the moment of the measure, is not prone to be affected by amplification and/or resonance effects if the ratio between the soil $\left(f_{S}\right)$ and building $\left(f_{B}\right)$ fundamental frequencies is less than 0.4. In fact the interactions between the resonance frequencies can be considered negligible. The impossibility to reach the roof of two-story buildings (the school and the town hall) led to a larger approximation to estimate the structure's vibration mode. Nevertheless we can state that the town hall $\left(f_{S} / f_{B}=0.38\right)$ and the church $\left(f_{S} / f_{B}=0.31-0.33\right)$ are safe, while the school $\left(f_{S} / f_{B}=0.49\right)$ is not.

Results regarding flood- and earthquake-related physical vulnerability represent basic but fundamental information for assessing risk and realizing an effective emergency plan for Dajç. Furthermore the proposed methodologies satisfy the cost-effectiveness and easy implementation requirements that are essential in a developing country community. Information about the vulnerability of a territory can be used: to plan and realize (i) structural interventions or (ii) non-structural interventions to reduce the exposure of the system to hazards; (iii) to improve societal coping abilities about the local risks and to prepare local authorities in the emergency management. In a social context as the considered one, significant structural interventions concerning the local vulnerability may be costly (table 1). Waiting for new and effective nonstructural measures by the local government, the adopted procedures for assessing flood- and earthquake-related physical vulnerability demonstrated to be suitable, in terms of costs and ease of use, for being adopted by the Dajç municipality in the field of emergency plan designing and disaster management.

\section{Conclusions}

The territory of the Dajç municipality has been repeatedly affected by floods (three main events in the last ten years) due to the overflowing of the Buna River and it is located within a high seismicity zone. This area is prevalently rural, with scattered small villages dispersed within the alluvial plain and linked by a poor road network. A multi-hazard analysis is fundamental to the development of communities like the Dajç one, which are in need of low-cost, easy-to-use technologies and procedures to 
evaluate the vulnerability of their territory to arrange the adequate countermeasures and to enhance the local community coping capacity.

The flood-related vulnerability of the area has been estimated computing the 2009-2011 flood episodes hydraulic data by means of the HEC-RAS open source software and plotting the results on an ArcGIS ${ }^{\circledR}$ platform. The effectiveness of the methodology has been tested comparing the results with the real scenarios. Steady flow simulations, using the expected river discharge value as input datum, demonstrated their validity in reproducing the locations of dykes overflowing due to surge events like the opening of a dam. All the results of the unsteady flow simulations, computing the 2009-2011 event flood hydrograph, accurately reproduced the inundated areas as occurred in the analysed days.

Furthermore, seismic vulnerability estimation for three strategic buildings has been chosen as the most rapid way to give the basic information to the administration in order to prepare an emergency plan. The used methodology was based on seismic noise analysis and was carried out using two Tromino ${ }^{\circledast}$ seismometers. Risks related to seismic amplification phenomena due to geological factors were evaluated for the three sites studying the $\mathrm{H} / \mathrm{V}$ curves, constrained by $V_{\mathrm{S}}$ velocities derived by the local lithology. Then the seismic vulnerability of the buildings themselves has been estimated studying the ratio between the soil $\left(f_{S}\right)$ and structure $\left(f_{B}\right)$ fundamental frequencies. For a structure to be safe this ratio must be lower than 0.4 to avoid frequency interactions. Two of the three studied buildings (Dajç town hall and church) resulted safe, while the local school resulted unsafe.

Therefore, the proposed methodologies can be used by the Dajç local community to enhance societal coping abilities since they are a good compromise between the required costs (in terms of time, materials, money and instruments), the relative simplicity of use and the achievable results. Further developments of this procedure could take into account a statistical approach, evaluating the intensity and density of the considered risk and generalizing the results for other infrastructure.

\section{Acknowledgements}

The authors are grateful to the Misericordia di Firenze Association and the Italian Civil Protection Department for getting us involved in this project. We wish to express gratitude to Fabrizio Nocchi and all the Albanian I Care volunteers who contributed efficiently to the fieldwork and were actively involved in the first national civil protection relief drill in Albania under the supervision of the Italian counterparts.

\section{Disclosure statement}

No potential conflict of interest was reported by the authors.

\section{References}

Ackerman CT. 2009. HEC-GeoRAS, GIS tool for support of HEC-RAS using ArcGis ${ }^{\circledR}$ user manual. Davis (CA): US Army Corps of Engineering.

Alcántara-Ayala I. 2002. Geomorphology, natural hazards, vulnerability and prevention of natural disasters in developing countries. Geomorphology. 47:107-124.

Allaraj S, Drishti B, Shkupi D, Gjata G. 2012. Some data on geohazards in Albania. Southeast Eur J Earth Obs Geom. 1:71-81.

Arai H, Tokimatsu H. 2004. S-wave velocity profiling by inversion of microtremor H/V spectrum. Bull Seismol Soc Am. 94:53-63. 
Barkau RL. 1992. UNET, one-dimensional unsteady flow through a full network of open channels, computer program. Davis (CA): US Army Corps of Engineers.

Becchi G, Dias Dos Santos V, Badji H. 2011. Disaster risk reduction capacity assessment report for Albania. United Nations Development Programme, Bureau for Crisis Prevention and Recovery Disaster Risk Reduction and Recovery Team Capacity for Disaster Reduction Initiative. UNDP (BCPR-CADRI).

Birkmann J. 2006. Measuring vulnerability to natural hazards. Tokyo: United Nations University Press.

Bogdani M. 2006. Risk assessment from flooding in the rivers of Albania. Paper presented at: 1st BALWOIS Conference; Ohrid, MAC.

Brunner GW. 2010a. HEC-RAS, river analysis system user manual - version 4.1. Davis (CA): US Army Corps of Engineering.

Brunner GW. 2010b. HEC-RAS, river analysis system hydraulic reference manual - version 4.1. Davis (CA): US Army Corps of Engineering.

Casas A, Benito G, Thorndycraft VR, Rico M. 2006. The topographic data source of digital terrain models as a key element in the accuracy of hydraulic flood modeling. Earth Surf Process Landforms. 31:444-456.

Castellaro S, Mulargia F. 2009. The effect of velocity inversions on H/V. Pure Appl Geophys. 166:567-592.

Çetinkaya S, Kaymaz ÇK. 2013. Evaluation of Lake Shkoder, Lake Ohrid and Prespa Lake shores on the rural development in Albania. Glob Adv Res J Geogr Reg Plann. 2:193-200.

Chow VT. 1959. Open-channel hydraulics. New York (NY): McGraw Hill.

Clinton JF, Bradford SC, Heaton TH, Favela J. 2006. The observed wander of the natural frequencies in a structure. Bull Seismol Soc Am. 96:237-257.

Costa L, Kropp JP. 2013. Linking components of vulnerability in theoretic frameworks and case studies. Sustain Sci. 8:1-9.

Cutter SL, Barnes L, Berry M, Burton C, Evans E, Tate E, Webb J. 2008. A place-based model for understanding community resilience to natural disasters. Glob Environ Change. 18:598-606.

Daj̧ Commune. 2008. Strategic development plan of Dajç commune.

Deininger K, Savastano S, Carletto C. 2012. Land fragmentation, cropland abandonment, and land market operation in Albania. World Develop. 40:2108-2122.

Del Gaudio V, Coccia S, Wasowski J, Gallipoli MR, Mucciarelli M. 2008. Detection of directivity in seismic site response from microtremor spectral analysis. Nat Hazards Earth Syst Sci. 8:751-762.

Ditommaso R, Mucciarelli M, Gallipoli MR, Ponzo FC. 2010. Effect of a single vibration building on free-field ground motion: numerical and experimental evidences. Bull Earthq Eng. 8:693-703.

Doornkamp JC. 1989. Hazards. In: McCall GJH, Marker BR, editors. Earth science mapping for planning, development and conservation. London: Graham \& Trotman; p. 157-173.

Fäh D, Kind F, Giardini D. 2001. A theoretical investigation of average H/V ratios. Geophys J Int. 145:535-549.

Field EH, Jacob KH. 1995. A comparison and test of various site-response estimation techniques, including three that are not reference-site dependent. Bull Seismol Soc Am. 85:1127-1143.

Fuchs S, Kuhlicke C, Meyer V. 2011. Editorial for the special issue: vulnerability to natural hazards - the challenge of integration. Nat Hazards. 58:609-619.

Gaetani F, Parodi A, Siccardi F, Miozzo D, Trasforini E. 2008. The structure, role and mandate of civil protection in disaster risk reduction for South Eastern Europe. South Eastern Europe Disaster Risk Mitigation and Adaptation Programme. International Centre on Environmental Monitoring Research Foundation (CIMA). 
Gallipoli MR, Mucciarelli M, Castro RR, Monachesi G, Contri P. 2004. Structure, soil-structure response and effects of damage based on observations of horizontal-to-vertical spectral ratios of microtremors. Soil Dyn Earthq Eng. 24:487-495.

Grazhdani S, Shumka S. 2007. An approach to mapping soil erosion by water with application to Albania. Desalination. 213:263-272.

Higgitt DL, Warburton J. 1999. Applications of differential GPS in upland fluvial geomorphology. Geomorphology. 29:121-134.

Hinkel J. 2011. Indicators of vulnerability and adaptive capacity: towards a clarification of the science-policy interface. Glob Environ Change. 21:198-208.

Hodgkinson PE, Stewart M. 1991. Coping with catastrophe. A handbook of disaster management. London: Taylor \& Francis/Routledge.

Ionescu C, Klein RJT, Hinkel J, Kumar KSK, Klein R. 2009. Towards a formal framework of vulnerability to climate change. Environ Model Assess. 14:1-16.

Kinzel PJ. 2008. In-river channel topographic surveys collected prior to and following elevated flows in the central Platte River, Nebraska, spring 2008. Data Series 380. Reston (VA): U.S. Geological Survey.

Lachet C, Hatzfeld D, Bard PY, Theodulidis N, Papaioannou C, Savvaidis A. 1996. Site effect and microzonation in the city of Thessaloniki (Greece). Comparison of different approaches. Bull Seismol Soc Am. 86:1692-1703.

Leica. 2002. GPS system 500: GPS equipment user manual, version 4.0. Heerbrugg $(\mathrm{CH})$ : Leica Geosystems.

Lekkas EL. 2000. Natural and technological catastrophes. Athens (GR): Access PrePress.

Mastin MC, Fossness RL. 2008. Bathymetry and near-river topography of the Naches and Yakima rivers at Union Gap and Selah Gap, Yakima Country, Washington, August 2008. Data Series 475. Reston (VA): U.S. Department of the Interior and U.S. Geological Survey.

McCall GJH. 1992. Natural and man-made hazards: their increasing importance in the end$20^{\text {th }}$ century world. In: McCall GJH, Laming DJC, Scott SC, editors. Geohazards natural and man-made. London: Chapman \& Hall; p. 1-4.

Morelli S, Segoni S, Manzo G, Ermini L, Catani F. 2012. Urban planning, flood risk and public policy: the case of the Arno River, Firenze, Italy. Appl Geogr. 34:205-218.

Mucciarelli M, Contri P, Monachesi G, Calvano G, Gallipoli MR. 2001. An empirical method to assess the seismic vulnerability of existing buildings using the HVSR technique. Pure Appl Geophys. 158:2635-2647.

Muço B, Georgi Alexiev G, Aliaj S, Elezi Z, Grecu B, Mandrescu N, Milutinovic Z, Radulian M, Ranguelov B, Shkupi D. 2012. Geohazards assessment and mapping of some Balkan countries. Nat Hazards. 64:943-981.

Nakamura Y. 1989. A method for dynamic characteristics estimations of subsurface using microtremors on the ground surface. Quarterly Report of Railway Technical Research Institute (RTRI). Vol. 30. Tokyo; p. 25-33.

Nolan SP, Toal D. 2008. A low directivity ultrasonic sensor for collision avoidance and station keeping on inspection-class AUVs. IMarEST J Mar Eng Technol. 7:1-11.

Pano N, Avdyli B. 1984. [Hydrology of Albania, a monograph]. Tirana: Academy of Science, Institute of Hydrometeorology; p. 94-146. Albanian.

Pano N, Avdyli B. 2009. A method to estimate Buna River discharge, Albania. Paper presented at: Hydrology Days 2009. Fort Collins (CO).

Paul BK. 2011. Hazards/disasters: special topics. In: Paul BK, editor. Environmental hazards and disasters: contexts, perspectives and management. Chichester: Wiley; p. 269-306.

Peyret F, Betaille D, Hintzy G. 2000. High-precision application of GPS in the field of realtime equipment positioning. Automat Constr. 9:299-314.

Pojani E, Tola M. 2010. The effect of climate change on the water sector with a case study of Albania: an economic perspective. Paper presented at: 2nd BALWOIS Conference; Ohrid, MAC. 
Qiriazi P, Sala S. 2000. Environmental problems of Albania. In: Buchroithner MF, editor. Remote sensing for environmental data in Albania: a strategy for integrated management. NATO Science Series 72. Amsterdam: Springer; p. 13-30

Rizos C. 2002. Making sense of the GPS techniques. In: Bossler J, Jenson J, McMaster R, Rizos C, editors. Manual of geospatial science and technology. London: Taylor \& Francis; p. 146-161.

Rizos C. 2008. Multi-constellation GNSS/RNSS from the perspective of high accuracy users in Australia. J Spat Sci. 53:29-63.

Scheidegger AE. 1994. Hazards: singularities in geomorphic systems. Geomorphology. 10:19-25.

Schmidt SM, Bernoulli D, Fügenschuh B, Matenco L, Schefer S, Schuster R, Tischler M, Ustaszewski K. 2008. The Alpine-Carpathian-Dinaridic orogenic system: correlation and evolution of tectonic units. Swiss J Geosci. 101:139-183.

SESAME. 2004. Guidelines for the implementation of the H/V spectral ratio technique on ambient vibrations. Measurements, processing and interpretation. SESAME European research project, WP12 - Deliverable D23.12, European Commission Research General Directorate, Project No. EVG1-CT-2000-00026 SESAME.

Stewart JP, Fenves GL. 1998. System identification for evaluating soil-structure interaction effects in buildings from strong motion recordings. Earthq Eng Struct D. 27:869-885.

Stratobërdha P, Xhelepi S, Abazi E, Zaimi K. 2008. Hydrologic regime and inundation floods in the Lezha catchment. Paper presented at: 3rd BALWOIS Conference; Ohrid, MAC.

Surace L. 1993. Il progetto igm95. [The igm95 project]. Bull Geod Sci Aff. 52:219-230. Italian.

Tate E, Maidment D. 1999. Flooding mapping using HEC-RAS and ArcView Gis. CRWR Online report 99-1.

Tetra Tech. 2009. Lower Puyallup River flood protection investigation, without-project analysis. Seattle (WA). Available from: http://www.co.pierce.wa.us/pc/services/home/envi ron/water/cip/pretf.htm

Thywissen K. 2006. Components of risk: a comparative glossary. Bonn: United Nations University Institute for Environment and Human Security (UNU-EHS).

Tobin GA, Montz BE. 2004. Natural hazards and technology: vulnerability, risk and community response in hazardous environments. In: Brunn SD, Cutter SL, Harrington JW, editors. Technoearth: geography and technology. Dordrecht: Kluwer Academic Publishers; p. 547-570.

United Nations Development Programme. 2003. Disaster risk assessment in Albania: executive summary report. Tirana: UNDP.

United Nations International Strategy for Disaster Reduction. 2009. UNISDR terminology on disaster risk reduction. Geneva, Switzerland. Available from: http://www.unisdr. org/files/7817_UNISDRTerminologyEnglish.pdf

[UNISDR] United Nations International Strategy for Disaster Reduction. 2010. One million safe schools and hospitals assessment and mitigation planning for risk reduction guide. UNISDR Regional Office for Asia and Pacific. Available from: http://www.unisdrapps.net/confluence/download/attachments/4554883/1MSSH_GuideNotes_AssessMit-Planning 070110.pdf

Varnes DJ. 1984. Landslide hazard zonation: a review of principles and practice. Paris: UNESCO Press.

VV.AA. 2011. Integrated project RIVA - sub project RIVA: environmental requalification of the basin of Skadar (Albania). Phase 2 - cognitive analysis. FPA Balkans - Line 2.3 environment and sustainable development.

World Bank. 2003. Water resources management in South Eastern Europe. Vol. II - country water notes and water fact sheets. Washington (DC): World Bank.

Zaçaj M, Muceku Y, Kiri E, Dushi E, Dogjani S, Kovaçi V. 2010. Kartografimi gjeologjikambjental per planifikimin e territorit. Rast studimi: comuna Dajç Bregu i Bunes, Shkoder. [Geologic-environmental mapping for territory planning. Case study: 
municipality of Dajç upon Buna, Shkoder]. Tirana: Polytechnic University of Tirana, Geosciences Institute. Albanian.

Zulherman MS, Yaakup A, Wongso J. 2006. GIS base modeling of the flood impacts on the urban development. Paper presented at: International Conference on Construction Industry 2006: Toward Innovative Approach in Construction and Property Development; Kuala Lumpur, Malaysia. 